\title{
Yūsuf Al-Qarḍāwī's Istinbāt Method and Its Implementation in the Moderation of Islamic Law
}

\author{
Ainol Yaqin \\ Institut Agama Islam Negeri Madura - Indonesia \\ ainulfairus@ymail.com
}

\begin{abstract}
This paper described the formulation of Yūsuf al-Qarḍāwī's isntinbāt method towards moderate figh. The choice of this theme was based on the existence of two demeanors in religion, between permissive and inclusive. Two main questions in this research were, first, how did Yūsuf al-Qarḍāwī formulate the istinbāt method for moderate fiqh? Second, how is the implementation of this method in formulating Islamic law? This paper concluded two things through a literature study with the descriptive-analytic method. First, there were six formulations of the istinbāt method for the moderation of Islamic law. a. Examining the maqāsid contained in the text before determining Islamic law, b. Linking texts and Islamic law with texts and other Islamic laws. c. Understandingtexts in the frame of asbāb (al-nuzūl or al-wurūd), both micro and macro. d. Distinguishing between constant maqāsisids and changing instruments. e. Adjusting between al-thawābit and almutaghayyirät. f. Observing the difference between worship and mu'ämalah in terms of wisdom, 'illah and maqāsid. Second, this method of istinbāt could produce fiqh with a flexible, elastic, dynamic, adaptive, and easy-to-practice.
\end{abstract}

Keyword: moderation; istinbāț method; Yūsuf al-Qarḍāwī; maqāṣid

[]

Tulisan ini mendeskripsikan formulasi metode isntinbāt Yūsuf al-Qardāwī ke arah fikih moderat. Pemilihan tema ini didasarkan atas adanya dua kecenderungan sikap dalam beragama, antara permisif dan inklusif. Dua pertanyaan pokok dalam penelitian ini yaitu, pertama, bagaimana Yūsuf al-Qarḍāwī memformulasikan metode istinbāt pada fikih moderat? Kedua, bagaimana implementasi metode tersebut dalam merumuskan hukum Islam? Melalui studi pustaka dengan metode deskriptif analitik, tulisan ini menyimpulkan dua hal. Pertama, terdapat enam formulasi metode istinbāț bagi moderasi hukum Islam. a. Menelaah maqāṣid yang terkandung di dalam nas sebelum menentukan hukum Islam, b. Mengaitkan nash dan hukum Islam dengan nash dan hukum Islam lainnya. $\mathrm{c}$. Memahami nash dalam bingkai asbāb (al-nuzūl atau al-wurūd), baik mikro maupun makro. d. Membedakan antara maqāșid yang konstan dan instrumen yang berubah. e. Menyesuaikan antara al-thawābit dan al-mutaghayyirāt. f. Mencermati perbedaan antara ibadah dan muamalah dari segi hikmah, 'illah dan maqāșid. Kedua, metode istinbāț ini dapat menghasilkan fikih yang berwajah fleksibel, elastis, dinamis, adaptif, dan mudah diamalkan.

Kata Kunci: moderasi; metode istinbāț, Yūsuf al-Qarḍāwī; maqāṣid 
Ainol Yaqin

\section{Introduction}

Some Muslims are rigid, stiff and strict in implementing Islamic teachings and intolerant to other groups and religions. They are exclusive, narrowminded, ghuluw (crossing the line) and try to achieve their goals through violence. Such religious manner and models arise because they comprehend the religious texts (nușūs al-sharī'ah) literally. They ignore the context (asbāb alnuzūl and asbāb al-wurūd) and reject the contextual understanding because they think it can reduce the purity of nușuss al-sharīah. Moreover, they tend to monopolize the truth on the understanding and interpretation of nuṣus alsharīah. As a result, they consider their understanding, opinions, and interpretations correct, while the opinions and understandings of other groups are wrong. So, they accuse groups outside their group of being wrong, heretical, and even infidels. They are also not good at distinguishing between religion (al$d \bar{i} n$ ) and religious thought (al-afkär al-dīniyah). The diversity of understandings, interpretations, and opinions based on the reasoning of nuṣuss al-sharīah is a necessity. ${ }^{1}$

At the same time, some other Muslims are very permissive. They are easy to justify something under the pretext of freedom and benefit. They prioritize reasoning in the hierarchy of Islamic legal arguments, then only use the Koran, al-Sunnah and al-ijmā'. Understanding and interpreting nuṣuss al-shari'ah tends to be non-literal, substantial, and contextual. This group examines the universal values contained in the text rather than sticking to the literal meaning. As a result, they deify the freedom of thought, assert the absolute freedom of religion, uphold equal rights and obligations between men and women regarding the separation of religion and state accede to the desacralization of Islamic turāth, etc. $^{2}$ Whereas for them, the benefits and enthusiasm of al-shari'ah can invalidate nușūs al-qațī (clear and definite text). ${ }^{3}$

1 Yūsuf Al-Qarḍāwī, Dirāsah fĩ Fiqh Maqāṣid al-Sharī’ah bayn al-Maqāṣid alKulliyah wa al-Nușūs al-Juz'iyah (Kairo: Dār al-Shurūq, 2008), 53-58; Șalāh AlȘāwī, Al-Tațarruf à̉-Dīnī (Al-Āfaq al-Dawliyah li I'lām, n.d.), 11-13; Ýūsuf AlQarḍ̄āì̄, Żăhirah al-Ghuluww fí al-Takfír (Kairo: Maktabah Wahbah, 1990), 2223.

2 ‘Abd al-Rahīm ibn Șamāyal Al-Salamī, Haqīqah al-Lībarāliyah wa Mawqif alIslām Minhā (Jeddah: Markaz al-Ta'șil li Dirāsāt wa al-Buhūth, 2009), $123,153,490$.

3 Sāilih Muhammad Al-Damìjī, Mawqif al-Lībarāliyah fì al-Bilād al-'Arabiyah min Muhkiamāt al-Dīn (Riyad: Maktabah al-Mulk, 1433), 589, 832. 
Meanwhile, according to the author, the mind cannot be used as the primary basis in the hierarchy of Islamic legal arguments. This rejection is based on several arguments. First, the mind has potential and limitations that sometimes lead to harm. Humans have lust that can deceive common sense so that what is considered excellent and beneficial by the mind is sometimes driven by lust. Therefore, the mind needs text instructions to show you the right and valuable way. Second, the mind is sometimes deceived by the atmosphere, situation, and environmental conditions. As a result, a situation that has mushroomed and has been running for a long time can be considered excellent and beneficial by reason, even though it conflicts with the values of the shari'ah.

Two extreme religious patterns above are contrary to Islamic teachings. Therefore, the istinbāt pattern for moderate jurisprudence is needed to produce Islamic law that is flexible, dynamic, easy to practice, far from rigidity and intolerance so that harmonious relations can be established in the lives of religious communities. This istinbāt pattern is in line with the rational manhaj of the șahābahs, tābi'īn and madhhab priests.

This article uses a critical analytical method to examine the moderate fiqh methodology proposed by Yūsuf al-Qarḍāwī. The author applies an interdisciplinary approach to data analysis, which is utilizing the science of ușūl alfiqh, philosophy, 'ulüm al-Qur'ān, 'ulüm al-hadìth, and maqāṣid al-sharīah as analysis tools. This article aims to determine the moderate fiqh istinbăt method formulated by al-Qarḍāwī and its application in formulating Islamic law. In addition, it is also to know the epistemology of al-Qarḍāwī's moderate fiqh istinbāt, to understand his position in the map of contemporary Islamic thinkers, and to know the development of ușül al-fiqh.

\section{Understanding Moderate Jurisprudence}

Moderate fiqh is formed from two words that both have their meaning; fiqh and moderate. Etymologically, Jurisprudence is the understanding, knowledge, ${ }^{4}$

4 'Abū Bakr Muḥammad ibn al-Ṭayyib Al-Bāqillānī, Al-Taqrīb wa al-Irshād (Beirut: Mu'assasah al-Risālah, 1998), vol. I; 171; Muhammad ibn al-Husayn alFarrā' Al-Baghdādī, Al-'Uddah fì Ușūl al-Fiqh, ed. Aḥmad ibn 'Alī (Riyāḍ: alMamlakah al-'Arabiyah al-Su'ūdiyah, 1993), vol. I; 67; Muhammad ibn 'Abd alHamīd Al-Asmandī, Badhl al-Nazar fi al-Ușūl (Kairo: Maktabah Dār al-Turāth, 1992), 6; 'Abdullāh ibn Ahmad ibn Muhammad ibn Qudāmah, Rawḍah al-Nāzir wa Jannah al-Manāzir fi Ușūl al-Fiqh (Riyad: Maktabah al-Rush, 1993), vol. I: 5ं8; 'Alī ibn 'Abd al-Kāfì al-Subkī Al-Subkī and 'Abd al-Wahhāb ibn 'Alī, Al-Ibhāj fī Sharh al-Minhāj (Kairo: Maktabah al-Kulliyat al-'Azhariyah, 1981), 28. 
or understanding of what the speaker is saying. ${ }^{5}$ Meanwhile, in terms of terminology, fiqh is knowledge of shara' 'amaliyah (deeds) laws resulting from tafșili arguments. 6 Meanwhile, the author tries to explain moderate etymologically as the middle between the two ends ${ }^{7}$ and the balance of everything. In Arabic, it is called al-wasatilyah (الوسطية), a mașdar șinā'î form of the word al-wasața. The word that corresponds to al-wasatiyah in Koran is found in three forms; isim, fi'il, and sifat. The word is embodied in al-Baqarah 143, 238; al-Qalam 28; al-'Ādiyāt 5; and al-Mā'idah 89. The word wasaț can mean fair or choice and mean being in the middle between two ends. At the same time, al-awsat is closer to the moderate meaning and far from the extreme meaning and can mean more critical, while al-wusțā means a phenomenon between two things. ${ }^{9}$

In terms of terminology, al-Qardāwī defines it as the equilibrium between two opposing or opposing sides. One side cannot be influenced by exposing the other side; one side does not take more rights, not transcend and marginalize the other side. The examples of two opposing sides are divinity (rabbāniyah) and humanity (insāniyah), spiritual (rūhaniyah) and materialistic (mādiyah), ukhrawiyah and dunyawiyah, revelation and reason, regarding the past (mādiyah) and regarding the future (mustaqbaliyah), individual (fardiyah) and collective (jamā'ilyah), realistic (wāqi'izah) and idealistic (mithāliyah), rights (huqūq) and obligations (wājibāt), constant (thabāt) and transformation (taghayyur), nașs and ijtihād, literalist (zāhiriyah) and substantive (maquassidiyah), 'äthar and logic (ra'y), and so on.10

${ }^{5}$ Muhammad ibn 'Umar ibn al-Ḥusayn Al-Rāzī, Al-Mahșūl fĩ Ușūl al-Fiqh, ed. TTahā Jābir Al-'Alwānī (Beirut: Mu'assasah al-Risālah, n.d.), vol. I; 78.

6 'Abdullāh ibn 'Umar Al-Bayḍāwī, Minhāj al-Wușūl 'ilā 'Ilm al-'Ușūl (Beirut: Dār ibn Hazm, 2008), 51.

7 Muhammad ibn Ya'qūb Al-Fayrūzabādī, Al-Qāmūs al-Muhīt (Beirut: Mu'assasah al-Risālah, 2005), 692; Shawqī Dayf, Al-Mu'jam al-Wasīt (Mesir: Maktabah al-Shurūq al-Dawliyah, 2004), 1031; Mahmūd ibn Ahmad Al-'Aynī, 'Umdah al-Qārī' Sharh Șahịh al-Bukhārī' (Beirut: Dār al-Kutub al-'Ilmiyah, 2001), vols XXII; 405.

8 Ibrāhīm Madkūr, Mu'jam al-Wajīz (Mesir: Wazārah al-Tarbiyah wa alTa'līm, 1994), 668; Dayf, Al-Mu'jam al-Wasīț, 1031.

${ }^{9}$ Yūsuf Al-Qarḍ̄āī, Fiqh al-Wasațiyah al-Islāmiyah wa al-Tajdīd; Ma'ālim wa Manārāt (Markaz al-Qarḍ̄āī, 2009), 18-19; Wahbah Al-Zuhaylī, Qaḍāyā al-Fiqh wa al-Fikr al-Mu'āșir (Damaskus: Dār al-Fikr, 2007), vols II; 549; Dayf, Al-Mu'jam al-Wasitt, 1031; Madkūr, Mu'jam al-Wajīz, 668.

10 Yūsuf Al-Qarḍ̄āī, Kalimāt fì al-Wasațiyah al-Islāmiyah wa Ma'ālimihā (Kairo: Dār al-Shurūq, 2011), 13; Yūsuf Al-Qarḍ̄wī, Al-Khașā'iṣ al-'Āmmah li al- 
'Abdullāh bin Bayyah defines moderate as a combination between universal (kullī) and partial (juz'î), the balance between maqāssid and furū', the everchanging integration of text and al-mașlahah, in setting fatwas. ${ }^{11}$ Wahbah alZuhayli describes the moderate as the middle in terms of faith, stance, behavior, systems, interactions, and morals from the universal paradigm. ${ }^{12}$ Muhammad Abū al-Fath defines moderate as an effort to achieve perfect harmony and asymmetry between separate components or integral components in a unified whole.13 While Muștafā La'azūzī defines moderate as a state of speech and behavior that shuns excessive and ignorant attitudes. It is praiseworthy and necessary for warding off radicalism and keeping away from tendencies to extremes and neglect. ${ }^{14}$ Based on some of the above definitions, it can be concluded that moderate fiqh is a knowledge of the laws of shara' 'amaliyah resulting from a study of nușūs al-juz'iyah, arguments of shara', and maqāṣid alsharīa $h$ by combining and integrating each other.

\section{Yūsuf al-Qarḍāwī's Version of the Istinbāt Methods of the Moderate Fiqh}

Moderate jurisprudence is drawn from the istinbāț method with a moderate pattern. Yūsuf al-Qarḍāwī, as a moderate thinker, formulated several methods of moderate fiqh istinbāt as follows.

\section{Examining the maqāṣid contained in nușūs al-sharīah before establishing Islamic law}

The first method of moderate fiqh istinbāt is to study and contemplate the maqāșid contained in the texts before formulating Islamic law. ${ }^{15}$ Every Islamic

Islām (Beirūt: Mu'assasah al-Risālah, 1983), 127; 'Iyād Kāmil Ibrāhīm al-Zībārī, Siyāsah al-Tadarruj fì al-Ahkām al-Shar'iyah (Beirut: Dār al-Kutub al-'Ilmiyah, 2017), 65; Thā'ir Ibrāhīm Khuḍī al-Shamrī, Al-Wasațiyah fi al-'Aqīdah alIslāmiyah (Beirut: Dār al-Kutub al-'Ilmiyah, 2005), 20; Al-Qarḍāwī, Fiqh alWasațiyah al-Islāmiyah wa al-Tajdīd; Ma'ālim wa Manārāt, 23.

11 'Abdullāh ibn Bayyah, 'Ma'āyīr al-Wasațiyah fī al-Fatwā', n.d.; 'Abdullah ibn Bayyah, Al-Irhāb: Al-Tashkhịs wa al-Hulūl (Riyad: Maktabah al-'Ubaykān, 2007), 100.

${ }_{12}$ Al-Zuhaylī, Qaḍāyā al-Fiqh wa al-Fikr al-Mu'āṣir, vols I; 578.

13 Muhammad Abū al-Fath al-Bayānūnī, Al-Wasațiyah Khașișah al-Ummah alIslāmiyah (Kairo: Dār Iqra', 2014), 11.

14 Mușțafā La'azūzī, Fițrah Allāh Tawāzun wa Wasațiyah, I'tidāl wa Hanīfiyah (Beirut: Dār al-Kutub al-'Ilmiyah, 2006), 10.

15 There are at least four maqāṣid-based ijtihād methods, a] understanding the texts and Islamic law based on maqāșid, b) combining universal maqāssid and partial propositions, c] take mașāliḥ and reject mafāsid, d) consider the 
law prescribed to human is intended to realize maqāșid al-sharīah. It is based on research on a number of the arguments of the Koran and Sunnah.16 Understanding maqūșid al-sharīah comprehensively and establishing Islamic law based on maqāșid considerations is very important in the logic of ijtihād.17 Maqāșid al-sharīah is not merely theoretical but is researched and applied in applying Islamic law, ${ }^{18}$ and it can be used as a source..$^{19}$ Any Islamic law that contradicts maqāșid is invalid. ${ }^{20}$ Therefore, faqīh, mujtahid, and mustanbiț must always think about maqāșid in every stipulating Islamic law. ${ }^{21}$ An opinion regarding Islamic law can be taken, followed, and applied if it emerges from a

consequences of Islamic law. Muhammad 'Abd al-'Ạtī Muhammad 'Alī, AlMaqāșid al-Shar'iyah wa Atharuhā fì al-Fiqh al-Islāmì (Kairo: Dār al-Hadīth, 2007), 267; Ahmad al-Raysūnī, Nazariyah al-Maqāșīd 'ind al-Imām al-Shāțībī (Riyad: Al-Dār al-'Alamiyah li al-Kitāb al-Islāmī wa al-Ma'hād al-'Alamī al-Fikr alIslāmī, 1995), 363; Al-Qarḍ̄wī, Dirāsah fì Fiqh Maqāṣid al-Sharī’ah bayn alMaqāșid al-Kulliyah wa al-Nușūs al-Juz'iyah, 155.

16 Muhammad al-Tāhir ibn 'Āshūr, Maqāsid al-Sharī'ah al-Islāmiyah (Yordania: Dār al-Nafā'is, 2001), 179; 'Abdullāh Ibn Bayyah, 'Alāqah Maqāșid alSharī'ah bi Ușūl al-Fiqh (London: Mu'assasah al-Furqān, 2006), 37-38; Haza' ibn 'Abdullāh ibn Ṣālih al-Ghāmidī, Muhāāwalāt al-Tajdīd fí Ușūl al-Fiqh wa Da'awātuh Dirāsah wa Taqwìm (Riyad: Wazārah al-Ta'līm al-'Ālī, 2008), vols II; 348; 'Alī, AlMaqāșid al-Shar'iyah wa Atharuhā fĩ al-Fiqh al-Islāmī, 19-20; Ahmad al-Raysūnī, Nazariyah al-Maqāșid 'ind al-Imām al-Shāțibī (Herndon: al-Ma'had al-'Âlamī lilfikr al-Islāmī, 1995), 145.

17 'Abdullāh ibn Bayyah, Mashāhid min al-Maqāṣid (Riyad: Dār Wujūh, 2012), 151; Ahmad al-Raysūnī, Al-Tajdīd al-'Ușūlì Nahw Siyāghah Tajdìdiyah li 'Ilm Ușūl al-Fiqh (Beirūt: Dār al-Kalimah, 2015), 725; Bayyah, 'Alāqah Maqāșid al-Sharī'ah bi Ușūl al-Fiqh, 95; al-Raysūnī, Nazariyah al-Maqāșīd 'inda al-Imām al-Shāțībī, 353; Ahmad al-Raysūnī, Muhāḍarāh fi Maqāṣid al-Sharī'ah (Kairo: Dār alKalimah, 2010), 287; Ibrāhīm ibn Mūsā ibn Muhammad al-Shāțibī, Al-Muwāfaqāt fì Ușūl al-Sharī'ah (Saudi: Wazārah al-Shu'ūn ai-Islāmiyah, n.d.), vols IV; 76; Nūr al-Dīn ibn Mukhtār al-Khādimī, Al-Ijtihād al-Maqāșidī (Qatar: Dār al-Kutub alQatariyah, 1998); 'Alal al-Fāsī, Maqāșid al-Sharī'ah al-Islāmiyyah wa Makārimuhā, 5th ed. (Rabat: Dār al-Gharb al-Islāmī, 1993), 165-66; Samīh 'Abd al-Wahhāb al-Jundī, Ahammiyah al-Maqāṣid fì al-Sharī'ah al-Islāmiyah (Beirut: Mu'assasah al-Risālah, 2008), 69; al-Ghāmidī, Muhāwalāt Aa-Tajdīd fí Usūl alFiqh wa Da'awātuh Dirāsah wa Taqwīm, 405-6; Aḥmad al-Raysūnī, Maqāșịid alMaqāșid (Beirūt: al-Shubkah al-'Arabiyah, 2013), 42.

18 'Abd al-Wahhāb ibn 'Alī ibn 'Abd al-Kāfĩ al-Subkī, Al-Ibhāj fì Sharh al-Minhāj (Kairo: Maktabah al-Kulliyat al-Azhariyah, 1981), vols III; 8-9; al-Jundī, Ahammiyah al-Maqāsid fì al-Sharī'ah al-Islāmiyah, 71.

19 Al-Raysūnī, Ai-Tajdìd al-'Ușūlì Naḥw Siyāghah Tajdìdiyah li 'Ilm Ușūl alFiqh, 725.

20 Hammādī 'Ubaydī, Al-Shāțibī wa Maqāṣid al-Sharī'ah (Beirut: Dār Qutaybah, 1992), 150; al-Shātibī, Al-Muwāfaqāt fì Ușūl al-Sharī'ah, vols IV; 252.

${ }^{21}$ Al-Raysūnī, Maqāșid al-Maqāṣid, 43; al-Raysūnī, Al-Tajdīd al-'Ușūlī Naḥw Siyāghah Tajdìdiyah li 'Il'm Ușūl al-Fiqh, 725. 
mujtahid who knows maqāșid al-sharīah extensively and deeply.22 A person who does not understand and pay attention to maqāșid in every commandment (al-'amr) and prohibition (al-nahy) he does not have the intelligence to stipulate Islamic law, ${ }^{23}$ because maqāșid is the essence, wisdom of al-sharìah ${ }^{24}$ and the foundation for mujtahids. ${ }^{25}$

Knowing the benefit of humans is an essential part of formulating Islamic law. ${ }^{26}$ Suppose Islamic law cannot realize benefit due to time, place, and condition. It cannot be implemented at that time, and its implementation is postponed until it can manifest the benefits. ${ }^{27}$ Analyzing reality and thinking about the application of maqāșid are very important in doing ijtihād. ${ }^{28}$ In this case, the significance observes the reality comprehensively in terms of time, place, local customs, and legal objects (person or public). ${ }^{29}$ In addition, because the texts are not likely to increase while the problems continue to develop, doing

${ }^{22}$ Al-Subkī, Al-Ibhāj fì Sharh al-Minhāj, vols III; 206.

23 'Abd al-Mulk ibn 'Abdullăh al-Juwaynī, Al-Burhān fì Ușūl al-Fiqh (Kairo: Dār al-Așar, n.d.), vols I; 295; Muhammad Sa'd ibn Ahmad ibn Mas'ūd al-Yūbī, Maqūșid al-Sharī'ah wa 'Alāqatuhā bi al-Adillah al-Shar'iyah (Riyad: Dār alHijrah, 1998), 50-51; 'Abd al-'Azīz ibn 'Abd al-Rahmān ibn Rabī'ah, 'Ilm Maqāșid al-Shāri' (Riyad: Maktabah al-Mulk, 2002), 59; 'Abd al-Qādir Harazullāh, Dawā̉ bit I'tibār al-Maqāșid fì Majāl al-Ijtihād wa Atharuhā al-Fiqhī (Riyad: Maktabah alRush, 2007), 173; Al-Raysūnī, Nazariyah al-Maqāșid 'ind al-Imām al-Shāțibī, 48.

24 Ahmad al-Raysūnī, 'Al-Maqāșid al-Sharīah wa Dawruhā fì Istinbāt alAhkām', Al-Muslim al-Mu'āșir 32, no. 128 (2008): 8; Bayyah, 'Alāqah Maqāṣid alSharī'ah bi Ușūl al-Fiqh, $13 \dot{3}$.

${ }^{25}$ Abū Hằ̄mid Muhammad Al-Ghazzālī, Haqīqah Al-Qawlaynī (Riyad: Majallah al-Jam'iyah al-Fiqhiyah al-Su'ūdiyah, n.d.), 312; 'Abd al-Raḥmān ibn Abū Bakr AlSuyūṭī, Al-Radd 'Alā Man Akhlad 'ilā al-Arḍ wa Jahila anna al-Ijtihād fì Kull 'Assr Farḍ (Kairo: Maktabah al-Thaqāfah al-Dīniyah, n.d.), 91; Ahmad al-Raysūnī, AlFikr al-Maqāșidì Qawā'iduh wa Fawā'iduh (Riyad: al-Dār al-Bayḍa', 1999), 91; alJundī, Ahammiyah al-Maqāṣid fì al-Sharī‘ah al-Islāmiyah, 105. 386.

${ }_{26}$ Muhammad Abū Zahrah, Ușūl al-Fiqh (Beirūt: Dār al-Fikr al-'Arabī, n.d.),

27 'Abd al-Majīd al-Najjār, Maqāșid al-Sharī'Ah bi 'Ab'āb Jadīdah (Beirut: Dār al-Gharab al-Islāmī, 2008), 20; Al-Ghāmidī, Muḥāwalāt al-Tajdīd fì Ușūl al-Fiqh wa Da'awātuh Dirāsah wa Taqwìm, vols II; 779.

28 Ahmad al-Raysūni, Min A'lām al-Fikr al-Maqāșidī (Beirut: Dār al-Hādi, 2003), 84ं; Al-Ghāmidī, Muhāawalāt al-Tajdìd fĩ Ușūl al-Fíqh wa Da'awātuh Dirāsah wa Taqwìm, vols II; 780.

29 Ahmad al-Raysūnī, Al-Taysīr al-Fiqhī (Beirut: Dār Ibn Hazm, 2007), 116; 'Ādil al-Shuwaykh, Ta'līl al-Ahkām fì al-Sharī'ah al-Islāmiyah (Ṭanța: Dār alBashīr, 2000), 220; Ismā'̄il Kawkasāl, Taghayyur al-Ahkām fì al-Sharīah alIslāmiyah (Beirut: Mu'assasah al-Risālah, 2000), 76. 
ijtihād based on maqāșid is necessary. ${ }^{30}$ Islamic law is applied with due observance of maqāșid by the conditions of the local community. ${ }^{31}$ To deny maqāsid is the same as eliminating the spirit in fiqh.32

An example related to this method is the beard problem. It is described in three sahịh traditions. It is essential to know the meaning of al-'amr in the editorial of the hadith. Is it an obligation, or is it just a sunnah?

Ibn ' Umar narrates the first hadith. The Holy Prophet said: 33

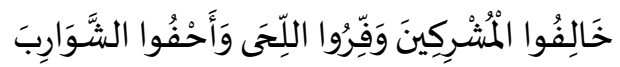

"Be different from the idolaters, lengthen the beard and cut the moustache."

In another narration from ibn 'Umar, he mentioned the Magi to the Messenger of Allah; then he said:34

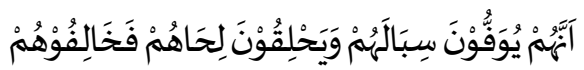

"They grow mustaches and shave beards, different from them."

The second hadith narrated by Abū Hurayrah. The Holy Prophet said: 35

$$
\text { جُزُوا الشَّوَارِبَ وَأَرْخُوا اللِّحَى خَالِفُوا الْمَجَوسنَ }
$$

"Cut the mustache, lengthen the beard and be different from the Magi."

The third hadīth narrated by Abū Umāmah al-Bāhilī. ${ }^{36}$

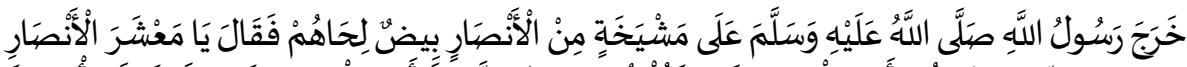

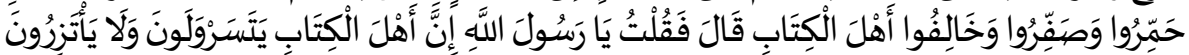

${ }^{30}$ Al-Khādimī, Al-Ijtihād al-Maqāșidī, vols II; 114; Al-Jundī, Ahammiyah alMaqāșid fì al-Sharīáah al-Islāmiyah, 63.

${ }_{31}$ Ahmad al-Raysūnī, Nazariyyāt al-Maqāșid 'ind al-Imām al-Shātibī, 149; Nūr al-Dīn ib̉n Mukhtār al-Khādimī, 'Ilm al-Maqāsid al-Shar'iyyah (Riyad: Maktabah al-'Ubaykān, 2001), 137; Al-Shātibī, Al-Muwāfaqāt fí Ușūl al-Sharī’ah, vols II; 53.

32 Ahmad al-Raysūnī, Al-Madkhal 'ilā Maqāșid al-Sharī'ah (Kairo: Dār alKalimah, 2009), 16.

33 'Ālī ibn Khalf ibn 'Abd al-Mālik, Sharh Saḥịh al-Bukhārī li Ibn Batțāl (Riyad: Maktabah al-Rushd, n.d.), vols IX; 146; Muhy al-Dīn ibn Sharf al-Nawawī, $A l$ Minhāj Sharh Sahīh Muslim Ibn al-Hajjāj (Kairo: al-Matba'ah al-Misriyah, 1929), 247; Al-'Aynī, 'Umdah Al-Qārī' Sharh Saḥ̄ḥ Al-Bukhārī', vols XXII; 71.

34 'Alī ibn Balbān al-Fārisī, Saḥīh İ̉n Hibbān bi Tartīb Ibn Balbān (Beirut: Mu'assasah al-Risālah, 1993), vols XX்II; 290.

35 'Abd al-Rahmān ibn Abū Bakr al-Suyūțī, Al-Dībāj 'alā Saḥīh Muslim Ibn alHajjāj (Riyad: Dằr ibn 'Affān, 1996), vols V; 38; Mūsā Shāhin Lāshin, Fath alMun'im Sharh Șaḥịh Muslim (Kairo: Dār al-Shurūq, 2002), vols II; 176-178; AlNawawī, Al-Minhàj Sharh Sahīh Muslim Ibn al-Hajjāj, vols III; 247.

36 Ahmad ibn Muhammad ibn Hanbal, Al-Musnad (Kairo: Dār al-Hadīth, 1995), vols XVI; 257-258. 


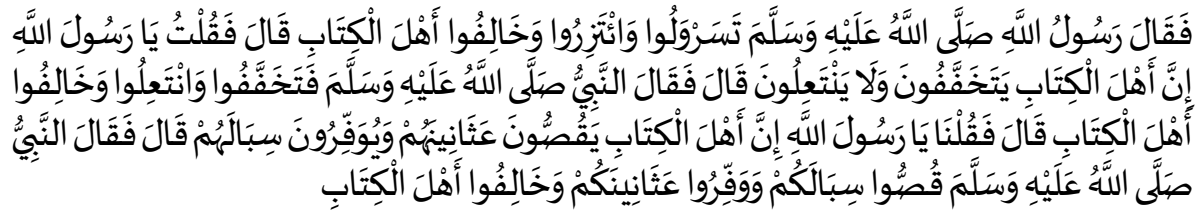

"Rasulullāh came to the old man of Ansar who had bleached his beard, he said:"O people of Ansar, red and yellow and be different from the Ahl al-Kitāb." I asked,"O Messenger of Allah, actually the Ahl al-Kitāb wears pants but does not have a sarong." He replied, "gloat and be different from the Ahl al-Kitāb". I asked, "O Messenger of Allah, actually Ahl al-Kitāb wears shoes but does not wear sandals", he replied, "Wear shoes and sandals and be different from Ahl al-Kitäb." We asked, "O Messenger of Allah, actually Ahl al-Kitāb cut beard and grow a mustache.", he said,"Cut your mustache and leave your beard and be different from the Ahl alKitāb."

If we observe the three hadiths above, we find a common thread that the maqāșid in the command to lengthen beard has a reason ('illah), which is not resembling the shape and appearance of non-Muslims. It is crucial to do, especially during the early days of the formation of Islam. Muslims must have an independent character that differentiates them from other people. Thus, if the beard problem is related to illah, then the rule of presence and absence of law, related to 'illah applies,37 namely المخالفة لغير المسلمين (different from nonMuslims).38 Moreover, المخالفة لغير المسلمين when viewed from the priority scale; darūriyah (immediate needs), hājiyah (secondary needs), and tahsiniyah (tertiary needs)). It is more in line with tahsiniyah, not häjiyah, let alone darüriyah. Therefore, it is not obligatory to synchronize with the Sunnah. This provision is in line with the wisdom of the promulgation of the law. ${ }^{39}$

As a Muslim-majority country, such as Indonesia, Pakistan, Bangladesh, Egypt, Malaysia, Nigeria, Turkey, Algeria, and Morocco, it is better to leave different symbols. So that inter-religious people can live in harmony, interact and communicate well. Thus, Islam rahmah li al-ālamīn can be realized through good words and deeds, warding off danger, and together creating unity and integrity and building national civilization.

${ }^{37}$ Ibn Qayyim al-Jawziyah, I'lām Al-Muwaqqi'īn 'an Rabb al-'Ālamīn (Riyad: Dār ibn al-Jawzī, 1423), vols V; 528; Muhammad Șidqī ibn Ahmad al-Būrnū, Mawsū'ah al-Qawā'id al-Fiqhiyah (Beirūt: Dār ibn Hazm, 2000), 195; Khālid ibn Ḥusayn ibn 'Abd al-Raḥmān, Jalīsuk fì Ramaḍān (Riyad: Dār Ṭawīq, 2002), 246.

38 Al-Qarḍ̄āī, Dirāsah fì Fiqh Maqāșid al-Sharī'ah bayn al-Maqāṣid alKulliyah wa al-Nușūṣ al-Juz'iyah, 157-58.

39 Al-Qarḍāwī, 158. 


\section{Linking texts and Islamic law with texts and other Islamic laws}

The second method is to combine one text with another and observe Islamic law extensively and comprehensively. ${ }^{40}$ The reading of texts systematically and comprehensively can combine al-kulliyāt al-'āmmah and al-adillah al-khāșșah ${ }^{41}$ so that maqāṣid al-sharī'ah can be known. ${ }^{42}$ Paying attention to particularities within a universal frame becomes necessary in applying particular arguments. ${ }^{43}$ Therefore, reading partial arguments when doing ijtihād must be accompanied by thinking about the universality of sharī'ah, al-maqāșid al-'ämmah, and comprehensive fiqh rules. ${ }^{4}$ Underestimating one of the results a mistake in understanding texts and determining Islamic law. This kind of recitation can only be done by knowing the maqāșid and mastering universal propositions. ${ }^{45}$ Suppose there is a contradiction between universal rules and particular texts. In that case, one should combine them by compiling texts on one theme and contemplating the universal rules of shari' $a h^{46}$ because the particular ones are only established by preserving the universal. It became clear after exposing the maqāsidid al-sharī'ah. ${ }^{47}$ Thus, the correct and perfect ijtihād is to study partial

40 Yūsuf al-Qardāwī, Al-Marja'iyah al-'Ulyā fĩ al-Islām li al-Qur'ān wa alSunnah (Kairo: Maktabah Wahbah, 2012), 174; Al-Qarḍāwī, Dirāsah fĩ Fiqh Maqāṣid al-Sharī'ah bayn al-Maqāṣid al-Kulliyah wa al-Nușūs al-Juz'iyah, 149.

${ }^{41}$ Al-Raysūnī, Nazariyah al-Maqāșid 'ind al-Imām al-Shàttibì, 369-70; 'Alī, AlMaqāșid al-Shar'iyah wa Atharuhā fí àl-Fiqh al-Islāmī, 268-69.

${ }_{42}$ Abū Hāmid Muhammad al-Ghazzālī, Al-Mustașfā min 'Ilm al-Ușūl (Beirut: Dār al-Kutub al-'Ilmiyah, 1413), vols I; 32; Nāșir ibn 'Abdullāh ibn 'Alī al-Qarāfì, Kitāb al-Furūq Anwār al-Burūq fi Anwā' al-Furūq (Kairo: Dār al-Salām, 2001), vols II; 670 .

43 'Abd al-Hamīd al-'Alamī, Manhaj al-Dars al-Dalālì 'ind al-Imām al-Shāțibī (Maroko: Wazằrah al-Awqāf wa al-Shu'ūn al-Islāmiyah, 2001), 125; Al-Shāțibī, Al-Muwāfaqāt fì Ușūl al-Sharī'ah, vols III; 5; 'Alī, Al-Maqāșid al-Shar'iyah wa Atharuhā fí al-Fiqh al-Islāmī, 269-70; Al-Raysūnī, Nazariyah al-Maqāșid 'ind alImām al-Shāțibī, 371; Rabī'ah, 'Ilm Maqāșid al-Shāri', 281.

${ }_{44}$ Al-Raysūnī, Nazariyah al-Maqāșid 'ind al-Imām al-Shāțibī, 370; 'Alī, AlMaqāṣid al-Shar'iyah wa Atharuhā fì al-Fiqh al-Islāmī, 269; Al-Qarḍāwī, AlMarja'iyah al-'Ulyā fi al-Islām li al-Qur'ān wa al-Sunnah, 226.

${ }^{45}$ Al-Raysūnī, Nazariyah al-Maqāșid 'ind al-Imām al-Shāțibī, 360.

${ }^{46}$ Al-Raysūnī, Muhāọdarāh fì Maqắsid al-Sharī'ah, 240.

47 'Abd al-Majīd Turkī, Munāzarāit fì Ușūl al-Sharī'ah al-Islāmiyah bayn Ibn Hazm wa al-Bājī (Beirut: Dār al-Gharab al-Islāmī, 1986), 490; Al-Shāțibī, AlMuwāfaqāt fì Ușūl al-Sharī'ah, vols III; 6-7; 'Alī, Al-Maqāṣid al-Shar'iyah wa Atharuhā fí al-Fiquh al-Islāmī, III; 6-7; Al-'Alamī, Manhaj al-Dars al-Dalālī 'ind alImām al-Shātibì, 126. 
propositions, universal propositions, and al-maqāșid al-'āmmah in responding to every problem of Islamic law.48

Integrating chapters of fiqh such as jurisprudence, mu'ämalah, munākahah, jināyah, sanctions, lawsuits, indictments, Islamic politics, jihād, and international relations is needed in doing jihad because all fiqh matters are interrelated. ${ }^{49} \mathrm{This}$ kind of method can provide solutions to various problems faced by Muslims in the era of globalization and disruption.

Combining verses with verses and hadiths is necessary to understand the text. It is because they are related and explained to each other. Other verses detail global verses, and other verses limit verses that are vague by other verses, verses that are muțlaq, and so on..$^{50}$ Likewise, hadith, when it is global, muțlaq, and vague, is detailed, limited, and clarified by other hadiths. ${ }^{51}$ Thus, integrating texts into a must to produce a complete understanding can reveal the text's purpose.

An example of this second method is isbāl. Some Hadith called it muțlaq editorial, and other hadiths use taqyid (limitation). Muslim narrated the hadith, which is muțlaq in nature from Abū Dhar. The Holy Prophet said:52

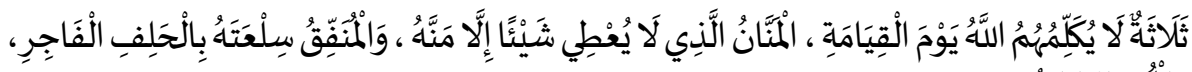

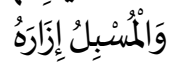

"Three groups of people who will not be spoken to by Allah SWT on the Day of Judgment. 1. al-mannān, namely people who do not give anything except to be brought up. 2. sellers who try to sell their goods under false oath. 3. the person holding out the sheath until it is below the ankles."

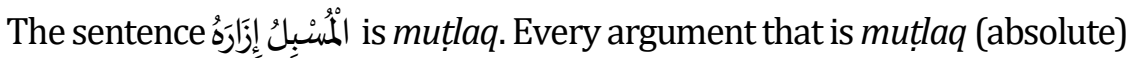
is also enforced absolutely until other arguments limit it. ${ }^{53}$ In connection with

48 Al-Raysūnī, Naẓariyah al-Maqāṣid 'ind al-Imām al-Shāțibī, 371; Rabī'ah, 'Ilm Maqāșid al-Shāri', 281.

49 Al-Qard̄āwī, Dirāsah fĩ Fiqh Maqāṣid al-Sharīah bayn al-Maqāṣid alKulliyah wa al-Nușūṣ al-Juz'iyah, 149.

50 Yūsuf al-Qarḍ̄āwī, Kayf Nata'mal ma'a al-Qur'ān al-'Azîm (Kairo: Dār alShurūq, 2000), 220.

51 Al-Qarḍ̄āīi, 123.

52 Iyāọ ib̉n Mūsā ibn 'Iyāọ al-Yahṣabī, Ikmāl Muslim bi Fawā'id Muslim (Beirut: Dằr al-Wafā', 1998), vol I; 114.

53 Muhammad ibn 'Alī ibn Muhammad al-Shawkānī, Irshād al-Fuhul 'ilā Tahqìq al-Haq min 'Ilm al-Ușūl (Riyad: Dār al-Faḍilah, 2000), 711; 'Alī ibn Muhammad al-Āmidī, Al-Iḥkām fì Ușūl al-Ahkām (Dār al-Șama'ī, 2003), vols III; 6; Muḥammad ibn 'Abdullāh al-Zarkashī, Al-Bahr al-Muhit fì Ușūl al-Fiqh (Kairo: Dār al-Ṣafwah, 1992), vols III; 416; Muḥammad ib̉n Niẓām al-Dīn al-Sahālawī, Fawātif 
Ainol Yaqin

the above hadith, there are several hadiths with the same theme that limit their absoluteness, namely the hadīths narrated by al-Bukhārī from 'Abdullāh ibn 'Umar. The Holy Prophet said:54

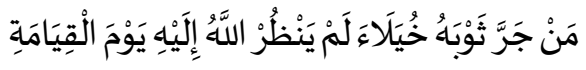

"On the Day of Resurrection, Allah will not see anyone pulling his clothes out of pride."

Muslim narrated another hadith with the same theme from Abū Hurayrah and Ibn 'Umar. The Holy Prophet said:55

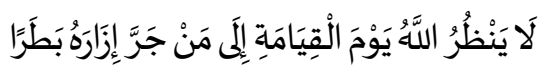

"On the Day of Resurrection, Allah will not look at anyone who sticks out a scabbard out of arrogance."

A hadith narrated by Muslim from ibn 'Umar, he heard Rasūlullāh said:56

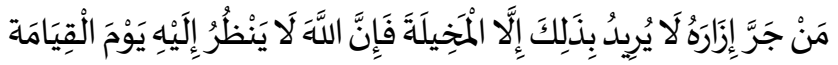

"Whoever extends the scabbard with the intention of boasting, Allah will not see it on the Day of Resurrection."

After combining some of these traditions, the first hadith, which is mutlaq, is limited (taqyīd) by the following three traditions. Al-Nawawi and Ibn Hajr assert that the absoluteness of the prohibition of lengthening clothes is limited by arrogance. ${ }^{57}$ More than that, Ibn Hajr explained that the sin of increasing clothes is due to pride. So that in terms of prohibition, $i s b \bar{a} l$ is simply due to arrogance. 58

al-Rahamūt (Beirut: Dār al-Kutub al-'Ilmiyah, 2002), vols I; 370; Al-Juwaynī, AlBurhàn fì Ușūl al-Fiqh, vols I; 431.

54 'Abd al-Rahmān ibn Abū Bakr al-Suyūțī, Al-Tawshīh Sharh al-Jāmi' al-Sahāh (Riyad: Maktabah al-Rush, 1998), vols VIII; 3563; Al-Yạ̣ṣabì, Ikmāl Muslim bi Fawā'id Muslim, vols I; 381.

${ }^{55}$ Al-Mālik, Sharḥ Șaḥihh al-Bukhārī li Ibn Batțāl, vols IX; 81.

56 Safì al-Rahmān al-Mubārakfūrī, Minnah al-Mun'im bi Sharh Sahīh Muslim (Riyad: Dār al-Salām, 1999), vols III; 398; Al-Nawawī, Al-Minhāj Sharh Saḥīh Muslim Ibn al-Hajjāj, vols XIV; 61; Al-Suyūțī, Al-Dībāj 'alā SSaḥịh Muslim Ib́n alHajjāj, vols V; 133; Al-Yahṣabī, Ikmāl Muslim bi Fawā'id Muslim, vols VI; 598-601.

57 Ahmad ibn Muhammad al-Khațīb al-Qasțalānī, Irshād al-Sārī 'ilā Sharh Sahịh al-Bukhārī (al-Mațba'ah al-Kubrā al-Amīriyah, 1323), vols VIII; 418; Ahmad ibn 'Alī ibn Hajar al-'Asqalānī, Fatḥ al-Bārī (Riyad: Maktabah al-Mulk, 2001), vols X; 270.

${ }^{58}$ Al-'Asqalānī, Fath al-Bārī, vols X; 270; Al-Qasțalānī, Irshād al-Sārī' 'ilā Sharh Șahịḥ al-Bukhārī, vols ViII; 418. 


\section{Understanding text in the asbāb al-nuzūl and asbāb al-wurūd frame}

Text can be understood correctly by studying the causes, environment, and conditions. The context behind the decline of the texts is known as asbāb alnuzūl al-Qur'än $n^{59}$ and $a s b a \bar{b} b$ al-wurūd al-hadīth ${ }^{60}$, both micro and macro. Micro $a s b \bar{a} b$ is a specific cause behind a revealed verse or hadith said. Meanwhile, the macro $a s b \bar{a} b$ is a generic cause that surrounds the Koran when revealed and the hadith when it is said, which includes socio-political, socio-economic, and sociocultural aspects. ${ }^{61}$ Knowing $a s b \bar{a} b$ is the entrance to understand the wisdom of the promulgation of the law, maqāsid al-sharīah, and the accuracy of understanding texts. ${ }^{62}$

Ibn Daqī al-'Īd explained that the deciphering of asbāb al-nuzūl is the best method in understanding the meanings of the Koran. ${ }^{63}$ In line with him, alWāhidì explained that the interpretation of a verse could not be known without first understanding the description of the asbāb al-nuzūl. ${ }^{64}$ Ibn Taymiyah also

59 'Abd al-Rahmān ibn Abū Bakr al-Suyūțī, Al-Itqān fì 'Ulūm al-Qur'ān (Beirut: Mu'assasah al-Risālah, 2008], 71; Mannā' Khalīl al-Qațāān, Mabāhith fì 'Ulūm alQur'ān (Kairo: Maktabah Wahbah, n.d.], 74.

60 Ibrāhīm ibn Muhammad ibn Kamāl al-Dīn, Al-Bayān wa al-Ta'rīf fì Asbāb Wurūd al-Hadìth al-Sharīf (Dār al-Hukūmah, 1329), 3.

${ }^{61}$ Rumadi, ed., Hasil-Hasil Muktamar ke-33 NU (Jakarta: Lembaga Ta'lif wan Nasyr PBNU, 2016), 154; Muhammad 'Abd al-'Azịm al-Zarqānī, Manāhil al-'Irfān fì 'Ulūm al-Qur'ān (Maṭba'ah 'İsā al-Bābī al-Halabī wa Sharakāh, n.d.), vols I; 108; Salmān ibn 'Umar al-Sanīdī, Tadabbur al-Qur'ān (Riyad: Maktabah al-Mulk, 2002), 100-101.

62 'Abd al-Karīm ibn Șālih ibn 'Abdullāh al-Zahrānī, 'Al-Mașābih fī Tafsīr alQur'ān al-'Azīm' (Jāmi'ah Ummu al-Qurā, 2000); Al-Suyūṭ̄, Al-İtqā̄n fì 'Ulūm alQur'ān; Țāriq As'ad Hilmi al-As'ad, 'Ilm Asbāb Wurūd al-Ḥadīth (Beirūt: Dār Ibn Hazm, 2001); Muhammad Ra'fat Sa'īd, Asbāb Wurūd al-Hadīth Taḥlīl wa Ta'sīs (Qatar: Kitāb al-Ummah, n.d.); Abdullah Saeed, Interpreting the Qur'ân: Toward a Comtemporary Approach (New York: Routledge, 2006); Mușțāā Al-Bughā and Muhy al-Dīn Mustawì, Al-Wādihh fì 'Ulūm al-Qur'ān (Damaskus: Dār al-Kalim alTayyib, 1998); 'Abd al-Sattār Jabr Ghāyab al-Ḥumūdī, 'Ilm Asbāb Nuzūl al-Qur'ān (Baghdad: Dīwān al-Waqf, 2014); 'Abdu al-Raḥmān ibn Nāṣir al-Sa'dī, Taysīr alKarīm al-Raḥmān fì Tafsīr Kalām al-Mannān (Riyad: Dār al-Salām, 2002); AlQaț̣ān, Mabāंhith fì 'Ulūm al-Qur'ān; Al-Qarḍāwī, Al-Marja 'iyah al-'Ulyā fí al-Islām li al-Qur'ān wa al-Sunnah.

63 Muhammad ibn 'Alī ibn Daqīq al-'Īd, Ihkām al-Ahkām Sharh 'Umdah alAhkām (Kairo: 'Ālam al-Kutub, 1987), 259.

64 'Alī ibn Aḥmad al-Wāhidì, Asbāb Nuzūl al-Qur'ān (Beirut: Dār al-Kutub al'Ilmiyah, 1991), 10; Muhammad ibn 'Abdullāh al-Zarkashī, Al-Burhān fì 'Ulūm alQur'ān (Beirut: Dār al-Ma'rifah, 1990), vols I; 117; Muhammad Abū Shuhbah, AlMadkhal li Dirāsah al-Qur'ān al-Karīm (Riyad: Dār al-Liwā',1987), 136; Abū 'Abd al-Rahmmān al-Suyūțī, Lubāb al-Nuqūl fí Asbāb al-Nuzūl (Beirūt: Mu'assasah alKutub al-Thaqāfiyah̆, n.d.), 7; Al-Suyūṭī, Al-Itqān fì 'Ulūm al-Qur'ān, 71; Al-Bughā 
explained that knowing asbāb al-nuzūl can help in understanding a verse. 65 Knowing asbāb al-nuzūl is a necessity in exploring the meaning of the Koran. It is for two reasons. First, maqāssid al-qur'än can only be known by understanding the circumstances surrounding them because one word may have many meanings according to the indication (qarinah) and the demands of the situation. Knowing asbāb al-nuzūl can clarify the ambiguity of the meaning that is in the Koran. Second, the lack of knowledge about asbāb al-nuzūl can confuse and result in a clear text becoming blurry, so that it often results in disagreements and differences in understanding. ${ }^{66}$ Ignoring the $a s b \bar{a} b$ al-nuzūl results in a failure to understand the texts and find maqāșid.

There are three ways to understand the texts; first, to think about the early days of Islam - the social, economic, political and cultural climates at that time -. This kind of contemplation can examine the meaning of a text. The error in interpreting texts is due to being trapped in the conditions of social reality in which they live, not referring to the conditions of social existence when the Koran was revealed. Second, to think about mental and social situations when the Koran was revealed. Third, to contemplate the time and place when the Koran was revealed. These three ways, when used, can lead to the correct meaning of the text because the illustrative language style is spoken according to the context.67

If only after studying the asbāb al-nuzūl is the most appropriate way to understand the Koran, then understanding the asbäb al-wurūd is the right way to grasp the meaning of the hadith. The characteristics of the Koran describe universal principles, while hadiths often respond to problems that are casuistic,

and Mustawī, Al-Wāḍh fì 'Ulūm al-Qur'ān, 60; Al-Qațān, Mabāhith fì 'Ulūm alQur'ān, 76; Al-Ḥumūdī, 'Ilm Asbāb Nuzūl al-Qur'ān, 51; Al-Zarqānī, Manāhil al'Irfān fì 'Ulūm al-Qur'ān, vols I; 109.

65 Ahmad ibn 'Abd al-Halīm ibn Taymiyah, Muqaddimah fì Ușūl al-Tafsīr, 1972, 47; Musā'id ibn Sulaymān ibn Nāṣir al-Ṭayyār, Sharh Muqaddìmah fì 'Ușūl al-Tafsīr (Riyāḍ: Dār ibn al-Jawzī, 1428), 67.

66 Muḥammad Jamāl al-Dīn al-Qāsimī, Maḥāsin al-Ta'wīl (Dār Ihyā' al-Kutub al-'Arabiyah, 1957), vols I; 28-29; Khālid 'Abd al-Rahmān al-'Ak, 'Usūl al-Tafsīr wa Qawā'Iduh (Beirut: Dār al-Nafā'is, 1986), 102; Muhammad al-Khuḍarī Bek, Ușūl al-Fiqh (Mesir: Maktabah al-Tijāriyah al-Kubrā, 1969), 210-11; Ảl-Sanīdī, Tadabbur al-Qur'ān, 101-2.

67 'Abd al-Raḥmān Hasan Hanbakah al-Mīdānī, Qawā'id al-Tadabbur alAmthāl li Kitābilläh 'Azz wa Jall (Beirut: Dār al-Qalam, 1980), 23-25; Māhir Husayn Haswah, Fiqh al-Wāqi' wa Atharuh fí al-Ijtihād (Yordania: al-Ma'had al‘Ālamī lilfikr al-Islāmī, 2009), 150. 
partial, and temporal. It also explained specific and complicated things that are not found in the Koran. Therefore, it is necessary to distinguish between particular and global, temporal and eternal, partial and universal. Placing each section according to its provisions then paying attention to the context, conditions, and asbāb al-wurūd can help correct understanding. ${ }^{68}$ In-depth research on a hadith can open the view that sometimes hadiths are said for specific reasons, related to certain 'illah, or answer a particular case that happened at that time.

The example for this method is the hadith regarding appointing a leader from the Quraish tribe. In a hadith narrated by Anas ibn Mālik, the Holy Prophet said: 69

"The leaders were from the tribe of Quraish."

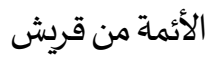

The above hadith requires a leader from the Quraish tribe. However, when scrutinized, the hadith speaks of siyāsah (politics), which is 'illah and whose purpose is reasonable ( $\left.m a^{\prime} q u \bar{l} l a l-m a^{\prime} n \bar{a}\right)$. Therefore, the provisions in the hadith do not apply absolutely but are casuistic, partial, and temporal to bring benefit and prevent damage at that time. In this connection, the rule of "law relating to the presence and absence of an 'illah" applies. In addition, the context of the hadith illustrates that the Quraysh tribe controlled the strength and ethnicity at that time. Based on this case, ibn Khaldūn stated that the caliphate and empire were built on stability and race. According to him, the requisite requirement of the Quraysh is to reject strife and contention because they have ethnicity and power. Al-Shāri' does not specify law on one time and one people but is related to al-kifäyah (capability). Therefore, the 'illah contained in the Quraysh is not purely tribal. Thus, the requirement for a leader is to come from a people who have the most influence and power in his time so that he is followed by his people and is in one good command and protection. ${ }^{70}$

The hadith thus explains the reality that happened at that time, and the essence of the leader's requirement is capability, not ethnicity. In modern times,

68 Al-Qarḍ̄wī, Kayf Nata'mal ma'a al-Qur'ān al-'Aẓ̂m, 146; Ḥaswah, Fiqh alWāqi' wa Atharuh fí al-Ijtihād, 149; 127.

69 Aḥmad ibn 'Alī ibn Mathanna al-Tamīmī, Musnad Abì Ya'lā al-Mawșalī (Beirut: Dār al-Thaqāfah al-'Arabiyah, 1992), 321.

70 'Abd al-Raḥmān ibn Khaldūn, Muqaddimah Ibn Khaldūn (Beirut: Dār alFikr, 2001), vols I; 371. 
countries that apply a democratic system, for example, the people's voice, determine a leader's election. The existence of majority vote support in general elections proves whether a leader is capable or not.

\section{Distinguishing between constant maqāṣid and changing instruments}

Every text that affirms the commands, prohibitions, and laws of Islam must be a purpose from al-Shāri'. As for the means as a means to an end is not specified in detail, because they can change according to changes in time, place, tradition, social, economic and political conditions. This fact allows people to engage in ijtihād in choosing, innovating, ${ }^{71}$ and developing it in line with the situation, local conditions, benefits, and is not fixated on certain instruments..$^{72}$ Al-Qarāfi explained that the source of Islamic law has two parts; first, al-maqāsisid are goals that contain mașlahah and mafsadah. Second, al-wasāil are the means used to achieve the goal. ${ }^{73}$ Ibn 'Āshur defined maqāșid as actions intended to be accomplished in various ways and pursued earnestly with complete obedience. While al-wasa'il are the means implied to obtain the law ideally, a goal is sometimes not achieved without means. ${ }^{74}$ The instrument law follows the maqāșid law, as explained by al-Jawziyah and al-Qarāfi that because maqāsisid (goals) cannot be performed without the instrument, the law accompanies the maqāșid law. ${ }^{75}$ Therefore, the means that lead to the prohibition, damage, and

${ }^{71}$ Muhammad al-Ghazzālī, al-Sunnah al-Nabawiyah bayn Ahl al-Sunnah wa Ahl al-Hadīth (Kairo: Dār al-Kitāb al-Mișrī, 2012), 160.

72 Al-Qarḍ̂āī, Dirāsah fì Fiqh Maqāșid al-Sharīah bayn al-Maqāṣid alKulliyah wa al-Nușūss al-Juz'iyah, 174.

73 Ahmad ibn Idrīs al-Qarāfī, Sharh Tanqīh al-Fuṣūl (Beirūt: Dār al-Fikr, 2004), 353; Ahmad ibn al-Qarāfī, Al-Zahìirah (Beirut: Dār al-Gharab al-Islāmī, 1994), vols I; 153; Muhammad Abū Zahrah, Ibn Hanbal Hayātuh wa 'Așruh Ārā'uh wa Fiqhuh (Kairo: Dār al-Fikr al-'Arabī, n.d.), 365; Muhammad Abū Zahrah, Mālik Hayātuh wa 'Așruh Ārā'uh wa Fiqhuh (Kairo: Dār al-Fikr al-'Arabī, n.d.), 432; 'Abd al-Majīd Jum'ah al-Jazā'irī, Al-Qawā'id al-Fiqhiyyah al-Mustakhraj min Kitāb I'lām al-Muwaqqi'īn (Dār ibn al-Qayyim, n.d.), 500; Am Nā'il al-Burkānī, Fiqh al-Wasā'il fí al-Sharì'ah al-Islāmiyah (Qatar: Wizārah al-Awqāf wa Shu'ūn al-Islāmiyah, 2007), 26; Al-Qarāfī, Kitāb al-Furūq Anwār al-Burūq fí Anwā' al-Furūq, vols II; 451.

${ }^{74}$ Muhammad al-Wakīlī, Fiqh al-Awwaliyāt Dirāsah fĩ al-Ḍawābit (Herndon: Ma'had al-'Ālamī lilfikr al-Islāmī, 1997), 237; 'Āshūr, Maqāṣid al-Sharī'ah alIslāmiyah, 415, 417; Al-Burkānī, Fiqh al-Wasā'il fí al-Sharī'ah àl-Islāmiyah, 30.

75 'Abd al-Rahmān Nāșir al-Sa'dī, Al-Qawã'id wa al-Ușūl al-Jāmi'ah (Kairo: Maṭba'ah al-Madanī, 1956), 10; 'Abd al-'Azīz ibn 'Abd al-Salām al-Sulamī, AlFawā'id fì Ikhtișār al-Maqāṣid (Beirut: Dār al-Fikr al-Mu'āșir, 1996), 53; 'Abd alNūr Bazā, Mașālih al-Insān Muqārabah Maqāșidiyah (Herndon: al-Ma'had al'Ālamī lilfikr al-Islāmì, 2008), 384. 
immorality of the law are prohibited (forbidden or impregnated). Meanwhile, the intermediaries who lead to obedience and benefit are ordered (obliged or punished). ${ }^{76}$

The majority of the texts of the Koran, which regulate mu'ämalah, were revealed globally. It contains general rules and basic principles. Thus, the role of reason in this field serves to find Islamic law by the goodness of humans and nature. ${ }^{77}$ In addition, most of the texts of al-sharìah only define al-mabādi' (principles) and al-maqāșid (goals) without specifying the mediums. This situation makes it easier for humans to fill by their problems. He can use the methods of qiyās, istihsān, mașlahah mursalah, 'urf, istishhāb and so on. However, al-Shāri' sometimes mentions specific instruments according to the place and time. Still, it is not intended as al-wasilah, which applies universally and eternally in every place and time.78

There are two kinds of wasā'il (means), first, al-wasă'il al-thābitah (constant means). It is interpreted as specific means that have been established by alShāri' to reach maqāșid. If the standards are not practiced or changed, it can cause the maqāșid to become corrupt and change. ${ }^{79}$ Second, al-wasā'il almutaghayyirah (means that are not fixed). It is defined as means that change according to changing situations and conditions. Maqāșid, in this case, is discovered through the process of ijtihād. ${ }^{80}$ Determining some of the means that are temporal and situational can lead to misinterpretation and slip in understanding nușūs al-sharīah. According to al-Qarḍāwī, the study of nusūṣ should be carried out until its substance, namely the established and eternal goal. Meanwhile, facilities can change and adapt according to changing times, places, conditions, environment, culture, human needs, science and technology, and other influences. 81

${ }^{76}$ Al-Raysūnī, Al-Fikr al-Maqāșidī Qawā'iduh wa Fawā'iduh, 81; Al-Wakīlī, Fiqh al-Awwaliyāt Dirāsah fì al-Dawābiț, 237-38; Zahrah, Ibn Hanbal Hayātuh wa 'Așruh Ārā'uh wa Fiqhuh, 365.

77 Wahbah al-Zuhaylī, Al-Wajīz fì Ușūl al-Fiqh (Beirut: Dār al-Fikr, 1999), 33.

${ }^{78}$ Sa'īd Ismā'îl 'Alī, Al-Sunnah al-Nabawiyah Ru'yah Tarbawiyah (Kairo: Dār al-Fikr al-'Arabī, 2002), 478; Al-Qarḍāwī, Dirāsah fì Fiqh Maqāṣid al-Sharī'ah bayn al-Maqāṣid al-Kulliyah wa al-Nușūs al-Juz'iyah, 176.

${ }^{79}$ Al-Khādimìi, Al-Ijtihād al-Maqāșidìi, vols I; 65-67.

80 Al-Khādimī, vols I; 67-68; Al-Burkānī, Fiqh al-Wasā'il fì al-Sharī'ah alIslāmiyah, 73.

${ }^{81}$ Mu'taz al-Khațīb, 'Manhajiyah al-Maqāṣid wa al-Wasā'il fī al-Ijtihād alFiqhī', Majallah al-Fikr al-Islāmī al-Mu'āṣir 18, no. 71 (2013): 69, 72; Al-Qarḍ̄āī, Dirāsah fì Fiqh Maqāṣid al-Sharī'ah bayn al-Maqāṣid al-Kulliyah wa al-Nușūṣ al- 
Ainol Yaqin

Instrument transformation is a necessity. It can metamorphose from one time to another and from one place to another. Therefore, if the text mentions a specific means, it explains a phenomenon at that time. So that these means cannot limit the universality of the text, it gives room for reason to think of other means that are more suitable, modern, and up-to-date in line with the progress of human civilization. ${ }^{82}$ The standards mentioned in the text may be updated with other, more relevant means. ${ }^{83}$ Even if you carry out the means that the text has noted, it can waste the more essential means in achieving the goal. Al-Shātibì stated that every argument in the Koran is absolute-without limitations, there are no specific provisions and standards-then the target text must be sought using the ability of reason. The majority of mu'ämalah and customary issues are related to this part, such as being fair, doing good, forgiving, patient, grateful, and other noble deeds. ${ }^{84}$ These noble qualities are maqāșid, which contain benefits. Meanwhile, the means not mentioned by al-Shāri' are intended so that people can freely develop them through the advancement of science and technology.

An example relevant to this method is the principle of deliberation, especially in political matters. Surah al-Shūrā Verse 38 explains this principle.

وَأَمْرُهُمْ شُورَى بَيْنَهُمْ

"And they gather amongst each other to conduct their affairs by mutual consultation."

Surah Ali 'Imrān Verse 159 also mentions this principle.

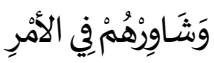

"and take counsel with them in the affair."

The two verses above explicitly explain the principle of deliberation in political affairs, state administration, and other civil matters. However, he did not specify

Juz'iyah, 176; Al-Qarḍāwī, Kayf Nata'mal ma'a al-Qur'ān al-'Azî̀m, 159; AlRaysūnī, Al-Fikr al-Maqāṣidì Qawā'iduh wa Fawā'iduh, 82-83, 88.

82 Al-Qarḍāwī, Dirāsah fi Fiqh Maqāșid al-Sharī'ah bayn al-Maqāṣid alKulliyah wa àl-Nușūṣ al-Juz'iyah, 176-77; Al-Qarḍ̄wī, Kayf Nata'mal ma'a alQur'ān al-'Azî̀m, 160; Al-Burkānī, Fiqh al-Wasā'il fì al-Sharī'ah al-Islāmiyah, 76.

${ }^{83} \mathrm{Al}$-Jawziyah, I'lām al-Muwaqqi'în 'an Rabb al-'Älamīn, vols IV; 355-356; AlRaysūnī, Nazariyah al-Maqāșid 'ind al-Imām al-Shāțibī, 364.

${ }^{84}$ Muhammad 'Imārah, Ma'rakah al-Islām wa Ușūl al-Hukm (Kairo: Dār alShurūq, 1997), 346; Sa'd al-Dīn al-'Uthmānī, Al-Dīn wa al-Siyāsah Tamyīz lā Fașl (Kairo: Dār al-Kalimah, 2015), 89; Khālid ibn 'Uthmān al-Sabt, Qawā'id al-Tafsìr Jam'ān wa Dirāsah (Dār ibn 'Affān, 1421), vols II; 773. 
the form of deliberation, the participants, the method of consideration, and choosing a leader.

The text did not specify specific instruments in deliberation. The aim is to solve problems in Muslims' lives, especially political, social and economic problems. Al-Shāri' gives breadth to Muslims in choosing and developing these instruments according to the times. ${ }^{85}$ Based on these principles, Indonesia, a democratic country, involves its people in electing executive and legislative institutions. The goal is that those elected can represent them to discuss the problems of the people, nation, and state for social justice for all Indonesian people. The representation of people's aspirations through these institutions is one of the many instruments in the principle of deliberation governed by the texts.

\section{Adjusting between al-thawābit and al-mutaghayyirāt}

On the one hand, Islamic law has an al-thabāt (constant) dimension, and the other has an al-taghayyur or al-murūnah (flexible) dimension. The moderate fiqh ijtihād method adapts and pays attention to both. The harmony of al-thabāt and al-murünah emanates from the Koran, which presents universal principles and global propositions. It is rare to find a detailed and partial description of the verses of al-ahkām. In addition, the majority of verses juz'iyāt (partial) in their designation to the law are in the form of zanni al-dalālah (multi-interpretation), and only a few are in the form of qaț'i al-dalālah (firm and definite). ${ }^{86} \mathrm{Al}$-nușūs al-zanniyāt opens the space for the emergence of various understandings and interpretations so that Islamic law as a product of ijtihād becomes a neverending treasure trove of Islamic intellectual property. He is always fresh, adaptive, and dynamic at the fast pace of human civilization.

Al-thawābit (constant provision) includes six things; a. the six pillars of faith. b. the five pillars of Islam. ${ }^{87}$ c. noble morals, such as justice, kindness, help, honesty, trustworthiness, avoiding prohibitions, compassion, patience, gratitude, and shame. d. qat'i haram, such as murder, adultery, sexual perversion, drinking alcohol, gambling, theft, seizure, witchcraft, usury, eating

85 Al-Qarḍāwī, Dirāsah fĩ Fiqh Maqāṣid al-Sharīah bayn al-Maqāṣid alKulliyah wa al-Nuṣūs al-Juz'iyah, 175; Al-Ghazzālī, Al-Sunnah al-Nabawiyah bayn Ahl al-Sunnah wa Ảhl al-Hadìth, 163; 'Imārah, Ma'rakah al-Islām wa Ușūl alHukm, 346.

86 Zahrah, Ușūl al-Fiqh, 92.

87 Khalī Mahmūid Na'rānī, Āthār al-Ḍarf fì Taghyīr al-Aḥkam al-Shar'iyah (Kairo: Dār ibn al-Jawzī, 2006), 132. 
orphan property, accusing adultery without evidence, fleeing war, false witnesses, disobedience to parents, breaking up a friendship, slander, slander, lying, and abusing human honour.88 e. The hidden haram things, such as pride, trickery, jealousy, hatred, showing off, being proud, following lust, and being greedy. f. the fundamental law of shara' which is qat'i, such as eating, drinking, dressing, buying and selling, financial transactions, marriage, divorce, testament, inheritance, and sanctions such as hudūd and qișāṣ.89 These laws are constant and qaț'í, both al-thubūt and al-dalālah. Ijtihād is forbidden on this kind of qat iti.

While al-mutaghayyirāt is related to the law of furü' (fiqh), which is produced from the text zannī al-thubūt, zannī al-dalālah, ${ }^{90}$ or both, rules resulting from ijtihäd can change due to changes in place, time, and human morals. ${ }^{91}$ Ijtihād activity in this zannī case is necessary for understanding the text and determining Islamic law. As a result of ijtihād, differences of opinion are commonplace; all contain the possibility of being right or wrong. Therefore, reforms and changes resulting from ijtihäd must occur in line with these changes. ${ }^{92}$ The reform of Islamic law is intended to achieve al-Shāri's goals, namely providing benefits and avoiding damage. 93

There are two kinds of Islamic law. First, it comes from a clear text and ijmā'. This first type of Islamic law has not changed. Second, Islamic law that results from ijtihād with the method of mașlahah, qiyās, or 'urf (customs). This second type changes. Everything that changes is a legal instrument and not a law itself. In general, al-Shāri' does not limit specific means in reaching the maqāṣid al-

88 Muhammad ibn Abū Bakr, Ighāthah al-Lahfān min Mașāyid al-Shayțān (Beirut: Dār al-Ma'rifah, 1975), vols I; 330-331; Muștafā Ahmad al-Zarqā, AlMadkhal al-Fiqhī al-'Ām (Damaskus: Dār al-Qalam, 2004), vols II; 942.

${ }^{89}$ Fathī al-Duraynī, Al-Manāhij al-Ușūliyah (Beirut: Mu'assasah al-Risālah, 2013), 138-39; Al-Qardāwī, Dirāsah fī Fiquh Maqāsid al-Sharī’ah bayn al-Maqāsid al-Kulliyah wa al-Nușūṣ al-Juz'iyah, 197-98; Al-Qarḍ̄wī, Al-Khașā'iș al-'Āmmah li al-Islām, 220-21.

90 'Abd al-Karīm ibn 'Alī ibn Muhammad al-Namlah, Ithāf Dhabī al-Bashā'ir bi Sharh Rawḍh al-Nāzir fì Ușūl al-Fiqh (Riyad: Dār al-'Āșimah, 1996), vols VIII; 12.

${ }_{91}^{1}$ Al-Zarqā, Al-Madkhal al-Fiqhī al-'Âm, vols II; 941.

92 'Alī Haydar, Durar al-Hukkām Sharḥ Majallah al-Ahkām (Riyad: Dār 'Ālam al-Kutub, 2003), vols I; 47.

93 Wahbah al-Zuhaylī, 'Ușūl al-Fiqh al-Islāmī (Damaskus: Dār al-Fikr, 2009), vols II; 1116. 
shari'ah but frees it so that humans can choose and develop better standards according to the situation at hand. ${ }^{4}$

Among the examples related to this method is the law of marriage registration. Registration of marriage in the past is unnecessary because the situation and conditions of society do not require it. However, it is different from the states, behavior, and morals in contemporary society, thus demanding changes in Islamic law. Another aspect, the development of administrative science, science, and technology, also affects changes in Islamic law. The status of marriage registration is thus obligatory. The law is based on al-mașlahah al'ämmah -maintaining the family order- and sadd al-dhari'ah -preventive measures to prevent harm to the wife and children-. In reality, unregistered marriage causes many problems. It harms women and children, such as domestic violence, sexual abuse, and neglect of wives and children.

\section{Examining the difference between worship and mu'ämalah from the aspect of wisdom, 'illah, and maqāṣid}

Among the istinbāt methods for moderate fiqh is the distinction between worship and mu'ämalah. The difference is in terms of wisdom, 'illah, and maqāṣid which are behind them. ${ }^{95}$ The basis of worship is worship and worship only to Allah regardless of the meaning, 'illah and maqāșid. Al-Shāțibī based this rule on several arguments: first, research some Islamic laws regarding worship. In this first case, the ta'abbudi element is the primary key. In many ways, the rules and conditions do not make sense. For example, the obligation to bathe after a husband and wife have intercourse, prayer movements, provisions regarding menstruation and childbirth - aborting prayers (not required to be replaced) but not aborting fasting (must be replaced). Al-Shāțibī emphasized;96

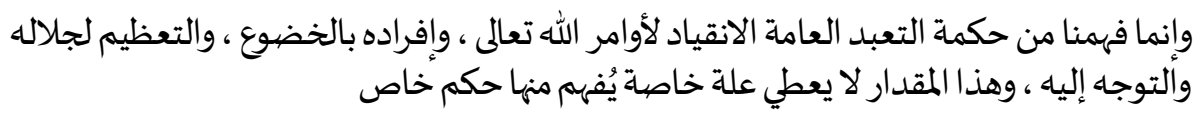

94 Muhammad 'Uthmān Shubayr, Al-Qawā'id al-Kulliyah wa al-Dawābit alFiqhiyah fì al-Sharī'ah al-Islāmiyah (Yordania: Dār al-Nafă'is, 2007), 263-65; AlZarqā, Al-Madkhal al-Fiqhī al-'Ám, vols II; 942.

95 'Abd al-Nūr Bazā, Nazariyah al-Ta'līl fĩ al-Fikrayn al-Kalāmī wa al-Ușūlī (Yordania: Ma'had al-'Ālamī lifikr al-Islāmī, 2011), 108; Al-Shātibī, Al-Muwāfaqāàt fï Ușūl al-Sharīah, vols II; 228.

96 Yūsuf Ahmad Muhammad al-Badawī, Maqāṣid al-Sharī'ah 'ind Ibn Taymiyah (Yordania: Dār aì-Nafā'is, 1999), 168; Al-Shāțibī, Al-Muwāfaqāt fī Ușūl al-Sharī'ah, vols II; 229. 
Ainol Yaqin

"The wisdom of worship in general is obeying Allah's commandments, obeying, exalting and facing only Him. It does not have a special 'illah which can be understood by special laws from it."

Second, logical reasoning argument. Al-Shāri' does not explain a proposition that shows breadth in worship. In contrast to mu'āmalah, which is looser. In fact, in terms of worship, the arguments are detailed. It shows that the provisions of worship stop at this limit. Likewise, al-munāsib -a trait seen as a legal motivation- is limited by something that has no equivalent in worship. Such as a problematic situation - due to traveling - allows qasr, ifțär, and jama' prayers. Meanwhile, difficulties other than travel cannot be a legal consideration.

Third, the worship services at the time of fatrah - the times when no Prophet was sent-could not be known by the scholars as they knew the meaning of 'illah and maqāșid in adat and mu'āmalah. According to al-Shātịibì, generally they were lost and deviated from the right path in terms of worship. They changed the previous sharī'ah according to their wishes. ${ }^{97}$ This situation shows that reason cannot know the meaning and provisions of worship, but requires guidance from the text. Therefore, in terms of worship, it must be returned to the provisions of al-Shāri', namely the element of ta'abbudi (merely worshipping Allah). ${ }^{98}$

Meanwhile, the basis in the field of mu'ämalah and custom is to pay attention to the meaning, 'illah, and maqāșid. ${ }^{99}$ Al-Shāțibì based this rule on several arguments, namely: first, research (istiqrā'). Every law that regulates custom and mu'ämalah aims for the benefit of humankind. On the other hand, all customary rules and mu'ämalah, which do not contain benefit or even cause harm, are prohibited. For example, the ability to buy and sell online, insurance, buy and sell credit systems, halal bi halal, subsets, alms earth, and tembang macapat. Second, reason can know 'illah, wisdom, and maqāșid in customs and $m u^{\prime}$ amalah through reasoning on the texts. Intellect can capture the benefits contained in these conditions. Third, the scholars can know 'illah, wisdom, and maqāsid in custom and mu'āmalah globally, even though during the fatrah period. They do that search so that it brings benefit. Al-sharīah then came to

${ }_{97}$ Al-Badawī, Maqāṣid al-Sharī'ah 'ind Ibn Taymiyah, 168.

98 Al-Shātibī, Al-Muwāfaqāt fī Usūl al-Sharī’ah, vols II; 231.

99 Al-Shāțibī, vols II; 232; Al-Qarḍ̄āīi, Dirāsah fì Fiqh Maqāṣid al-Sharīah bayn al-Maqășsid al-Kulliyah wa al-Nușūṣ al-Juz'iyah, 202; Al-Yūbī, Maqāṣid alSharī'ah wa 'Álāqatuhā bi al-Adillah àl-Shar'iyah, 412; Al-Badawī, Maqāșid alSharī'ah 'ind Ibn Taymiyah, 168. 
perfect it. Therefore, al-Shāri' confirmed several laws that were already in effect in the era of ignorance, such as diyat, qasāmah, gathering on Friday to listen to the sermon, qiräd, kiswah (Kabah clothes), and all the deeds, transactions, and customs that good that makes sense. ${ }^{100}$

An example of this method is regarding the law of productive waqf. Based on the purpose of waqf, which is to provide for the welfare of the poor, the waqf objects may be managed productively. Utilizing waqf property so that it brings many benefits to people's lives is justified by sharīah. Management and distribution of waqf are only for the benefit. Therefore, the näzir is required to see the development of the era, place, and benefit. The results of productive waqf can be distributed to community guidance and development programs, such as; the social sector in the form of building bridges, public restrooms, mosques; education sector in the form of scholarships for low-income families, establishing schools, libraries, skills training; health sector in the form of medical assistance for the poor and training in making herbal medicines; economic sector in the form of capital assistance and development, agricultural business development, livestock breeding; da'wah in the form of preaching, teacher salaries and wages for imams and mosque administrators.

\section{Conclusion}

Based on the description above, this paper concludes that, first, the istinbāt method for moderate fiq $h$ is indispensable to produce Islamic law that is flexible, elastic, adaptive, easy to practice and to spread benefit. The istinbāt method takes into account the relationship between texts, maqāsid, reality, and the present context. With it, jurisprudence can avoid extremities and tendencies towards conservatives and liberals. This method integrates naql and reason, text, context, and maqāșid al-sharīah, maqāșid al-sharīah and furū' (fiqh matters), kullì (universal) and juz'î (partial), as well as the universality of texts and the specificity of the situation. Second, the istinbāt method for moderate fiqh by Yūsuf al-Qarḍāwī as follows. a. Examining the maqāṣid contained in the texts before determining Islamic law. b. Linking texts and Islamic law with texts and other Islamic laws. c. Understanding texts in the frame of asbāb al-nuzūl or alwurūd, both micro and macro. d. Distinguishing between constant maqāṣid and

100 Al-Shātịī, Al-Muwāfaqāt fĩ Ușūl al-Sharī'ah, vols II; 232-233. 
changing instruments. e. Adjusting between al-thawābit and al-mutaghayyirāt. f. Observing the differences between the fields of worship and mu'ämalah in terms of wisdom, 'illah and maqāṣid.[a]

\section{BIBLIOGRAPHY}

Al-'Alamī, 'Abd al-Hamīd. Manhaj al-Dars al-Dalālì 'ind al-Imām al-Shāțibì. Maroko: Wizārah al-Awqāf wa al-Shu'ūn al-Islāmiyah, 2001.

'Alī, Muhammad 'Abd al-'Āṭi Muhammad. Al-Maqāṣid al-Shar'iyah wa Atharuhā fì al-Fiqh al-Islāmī. Kairo: Dār al-Hadīth, 2007.

'Alī, Sa'īd Ismā'īl. Al-Sunnah al-Nabawiyah Ru'yah Tarbawiyah. Kairo: Dār al-Fikr al-'Arabī, 2002.

Al-'Ak, Khālid 'Abd al-Raḥmān. 'Ușūl al-Tafsīr wa Qawā'iduh. Beirut: Dār al-Nafā'is, 1986.

Al-Āmidī, 'Alī ibn Muḥammad. Al-Iḥkām fì Ușūl al-Aḥkām. Dār al-Ṣama'ī, 2003.

Al-As‘ad, Ṭāriq As‘ad Hilmi. 'Ilm Asbāb Wurūd al-Hadīth. Beirūt: Dār Ibn Hazm, 2001.

Al-Asmandī, Muhammad ibn 'Abd al-Hamīd. Badhl al-Naẓar fĩ al-Ușūl. Kairo: Maktabah Dār al-Turāth, 1992.

Al-'Asqalānī, Aḥmad ibn 'Alī ibn Hajar. Fatḥ al-Bārī. Riyad: Maktabah alMulk, 2001.

'Āshūr, Muhammad al-Ṭāhir ibn. Maqāṣid al-Sharī’ah al-Islāmiyah. Yordania: Dār al-Nafā'is, 2001.

Al-'Aynī, Maḥmūd ibn Aḥmad. 'Umdah al-Qārī' Sharh Saḥīh al-Bukhārī. Beirut: Dār al-Kutub al-'Ilmiyah, 2001.

Al-Badawī, Yūsuf Aḥmad Muhammad. Maqāṣid al-Sharī'ah 'ind Ibn Taymiyah. Yordania: Dār al-Nafā'is, 1999.

Al-Baghdādī, Muhammad ibn al-Husayn al-Farrā'. Al-'Uddah fì Ușūl alFiqh. Edited by Aḥmad ibn 'Alī. Riyāọ: al-Mamlakah al-'Arabiyah alSu'ūdiyah, 1993.

Bakr, Muḥammad ibn Abū. Ighāthah al-Lahfān min Mașāyid al-Shayțān. Beirut: Dār al-Ma'rifah, 1975.

Al-Bāqillānī, 'Abū Bakr Muḥammad ibn al-Ṭayyib. Al-Taqrīb wa al-Irshād. 
Beirut: Mu'assasah al-Risālah, 1998.

Al-Bayānūnī, Muhammad Abū al-Fath. Al-Wasațiyah Khașịṣah al-Ummah al-Islāmiyah. Kairo: Dār Iqra', 2014.

Al-Bayḍāwī, 'Abdullāh ibn 'Umar. Minhāj al-Wuṣūl 'ilā 'Ilm al-Ușūl. Beirut: Dār ibn Hazm, 2008.

Bayyah, 'Abdullāh Ibn. 'Alāqah Maqāṣid al-Sharī'ah bi Ușūl al-Fiqh. London: Mu'assasah al-Furqān, 2006.

———. Al-Irhāb: Al-Tashkhīṣ wa al-Hulūl. Riyad: Maktabah al-'Ubaykān, 2007.

———. 'Ma'āyīr al-Wasațiyah fī al-Fatwā', n.d.

_——. Mashāhid min al-Maqāṣid. Riyad: Dār Wujūh, 2012.

Bazā, 'Abd al-Nūr. Mașāliḥ al-Insān Muqārabah Maqāṣidiyah. Herndon: alMa'had al-'Ālamī li al-Fikr al-Islāmī, 2008.

_-_. Nazariyah al-Ta'līl fĩ al-Fikrayn al-Kalāmī wa al-Ușūlī. Yordania: Ma'had al-'Ālamī li Fikr al-Islāmī, 2011.

Bek, Muhammad al-Khuḍarī. Ușūl al-Fiqh. Mesir: Maktabah al-Tijāriyah al-Kubrā, 1969.

Al-Bughā, Mușțafā, and Muhy al-Dīn Mustawī. Al-Wādịh fí 'Ulūm al-Qur'ān. Damaskus: Dār al-Kalim al-Tayyib, 1998.

Al-Burkānī, Am Nā'il. Fiqh al-Wasā'il fì al-Sharī'ah al-Islāmiyah. Qatar: Wizārah al-Awqāf wa Shu'ūn al-Islāmiyah, 2007.

Al-Būrnū, Muḥammad Ṣidqī ibn Aḥmad. Mawsū'ah al-Qawā'id al-Fiqhiyah. Beirūt: Dār ibn Hazm, 2000.

Al-Damījī, Șāliḥ Muḥammad. Mawqif al-Lībarāliyah fĩ al-Bilād al-'Arabiyah min Muhkkamāt al-Dīn. Riyad: Maktabah al-Mulk, 1433.

Dayf, Shawqī. Al-Mu'jam al-Wasīt. Mesir: Maktabah al-Shurūq alDawliyah, 2004.

Al-Dīn, Ibrāhīm ibn Muhammad ibn Kamāl. Al-Bayān wa al-Ta'rīf fì Asbāb Wurūd al-Hadīth al-Sharīf. Dār al-Ḥukūmah, 1329.

Al-Duraynī, Fatḥ̄. Al-Manāhij al-Ușūliyah. Beirut: Mu'assasah al-Risālah, 2013.

Al-Fārisī, 'Alī ibn Balbān. Șahīh Ibn Hibbān bi Tartīb Ibn Balbān. Beirut: Mu'assasah al-Risālah, 1993.

Al-Fāsī, 'Alal. Maqāṣid al-Sharī'ah al-Islāmiyyah wa Makārimuhā. 5th ed. Rabat: Dār al-Gharb al-Islāmī, 1993. 
Ainol Yaqin

Al-Fayrūzabādī, Muhammad ibn Ya'qūb. Al-Qāmūs al-Muḥiț. Beirut: Mu'assasah al-Risālah, 2005.

Al-Ghāmidī, Haza' ibn 'Abdullāh ibn Șālih. Muhāwalāt al-Tajdīd fĩ Ușūl alFiqh wa Da'awātuh Dirāsah wa Taqwīm. Riyad: Wizārah al-Ta'līm al'Ālī, 2008.

Al-Ghazzālī, Abū Hāmid Muhammad. Al-Mustaṣfā min 'Ilm al-Ușūl. Beirut: Dār al-Kutub al-'Ilmiyah, 1413.

- - . Haqīqah al-Qawlaynī. Riyad: Majallah al-Jam'iyah al-Fiqhiyah alSu'ūdiyah, n.d.

Al-Ghazzālī, Muhammad. Al-Sunnah al-Nabawiyah bayn Ahl al-Sunnah wa Ahl al-Hadìth. Kairo: Dār al-Kitāb al-Mișrī, 2012.

Ḥanbal, Aḥmad ibn Muhammad ibn. Al-Musnad. Kairo: Dār al-Hadīth, 1995.

Harazullāh, 'Abd al-Qādir. Dawābiț I'tibār al-Maqāșid fì Majāl al-Ijtihād wa Atharuhä al-Fiqhī. Riyad: Maktabah al-Rush, 2007.

Ḥaswah, Māhir Husayn. Fiqh al-Wāqi' wa Atharuh fí al-Ijtihād. Yordania: al-Ma'had al-'Ālamī li al-Fikr al-Islāmī, 2009.

Ḥaydar, 'Alī. Durar al-Hukkām Sharḥ Majallah al-Ahkām. Riyad: Dār 'Ālam al-Kutub, 2003.

Al-Ḥumūdī, 'Abd al-Sattār Jabr Ghāyab. 'Ilm Asbāb Nuzūl al-Qur'ān. Baghdad: Dīwān al-Waqf, 2014.

Al-'Īd, Muḥammad ibn 'Alī ibn Daqīq. Ihkām al-Aḥkām Sharḥ 'Umdah alAhkām. Kairo: 'Ālam al-Kutub, 1987.

'Imārah, Muhammad. Ma'rakah al-Islām wa Ușūl al-Hukm. Kairo: Dār alShurūq, 1997.

Al-Jawziyah, Ibn Qayyim. I'lām al-Muwaqqi'în 'an Rabb al-'Ālamīn. Riyad: Dār ibn al-Jawzī, 1423.

Al-Jazā'irī, 'Abd al-Majīd Jum'ah. Al-Qawā'id al-Fiqhiyyah al-Mustakhraj min Kitāb I'lām al-Muwaqqi'în. Dār ibn al-Qayyim, n.d.

Al-Jundī, Samīh 'Abd al-Wahhāb. Ahammiyah al-Maqāṣid fì al-Sharīa ah alIslämiyah. Beirut: Mu'assasah al-Risālah, 2008.

Al-Juwaynī, 'Abd al-Mulk ibn 'Abdullāh. Al-Burhān fi Ușūl al-Fiqh. Kairo: Dār al-Așar, n.d.

Kawkasāl, Ismā'îl. Taghayyur al-Ahkām fì al-Sharīah al-Islāmiyah. Beirut: Mu'assasah al-Risālah, 2000.

Al-Khādimī, Nūr al-Dīn ibn Mukhtār. 'Ilm al-Maqāṣid al-Shar'iyah. Riyad: 
Maktabah al-'Ubaykān, 2001.

———. Al-Ijtihād al-Maqāṣsidī. Qatar: Dār al-Kutub al-Qatariyah, 1998.

Khaldūn, 'Abd al-Raḥmān ibn. Muqaddimah Ibn Khaldūn. Beirut: Dār alFikr, 2001.

Al-Khațīb, Mu'taz. 'Manhajiyah al-Maqāṣid wa al-Wasā'il fĩ al-Ijtihād alFiqhī'. Majallah al-Fikr al-Islāmī al-Mu'āṣir 18, no. 71 (2013).

La'azūzī, Mușțafā. Fițrah Allāh Tawāzun wa Wasațiyah, I'tidāl wa Haniffiyah. Beirut: Dār al-Kutub al-'Ilmiyah, 2006.

Lāshin, Mūsā Shāhin. Fatḥ al-Mun'im Sharh Șaḥịh Muslim. Kairo: Dār alShurūq, 2002.

Madkūr, Ibrāhīm. Mu'jam al-Wajīz. Mesir: Wizārah al-Tarbiyah wa alTa'līm, 1994.

Al-Mālik, 'Ālī ibn Khalf ibn 'Abd. Sharh Sahịhh al-Bukhārī li Ibn Batțāl. Riyad: Maktabah al-Rushd, n.d.

Al-Mīdānī, 'Abd al-Raḥmān Ḥasan Hanbakah. Qawā'id al-Tadabbur alAmthāl li Kitābillāh 'Azz wa Jall. Beirut: Dār al-Qalam, 1980.

Al-Mubārakfūrī, Șafī al-Raḥmān. Minnah al-Mun'im bi Sharḥ Șahịḥ Muslim. Riyad: Dār al-Salām, 1999.

Al-Najjār, 'Abd al-Majīd. Maqāșid al-Sharī’ah bi 'Ab'āb Jadīdah. Beirut: Dār al-Gharab al-Islāmī, 2008.

Al-Namlah, 'Abd al-Karīm ibn 'Alī ibn Muhammad. Ithāf Dhabī al-Bashā'ir bi Sharh Rawdah al-Nāzir fì Ușūl al-Fiqh. Riyad: Dār al-'Āṣimah, 1996.

Na'rānī, Khalīl Mahmūù. Āthār al-Darf fì Taghyīr al-Aḥkam al-Shar'iyah. Kairo: Dār ibn al-Jawzī, 2006.

Al-Nawawī, Muhy al-Dīn ibn Sharf. Al-Minhāj Sharh Șahīḥ Muslim Ibn alHajjāj. Kairo: al-Mațba'ah al-Misriyah, 1929.

Al-Qarāfì, Aḥmad ibn. Al-Ẓahīrah. Beirut: Dār al-Gharab al-Islāmī, 1994.

-_- Sharh Tanqīh al-Fușūl. Beirūt: Dār al-Fikr, 2004.

Al-Qarāfī, Nāșir ibn 'Abdullāh ibn 'Alī. Kitāb al-Furūq Anwār al-Burūq fí Anwā' al-Furūq. Kairo: Dār al-Salām, 2001.

Al-Qarḍāwī, Yūsuf. Al-Khașā'iș al-'Āmmah li al-Islām. Beirūt: Mu'assasah al-Risālah, 1983.

-_- Al-Marja'iyah al-'Ulyā fĩ al-Islām li al-Qur'ān wa al-Sunnah. Kairo: Maktabah Wahbah, 2012. 
Ainol Yaqin

———. Dirāsah fï Fiqh Maqāṣid al-Aharī’ah bayn al-Maqāṣid al-Kulliyah wa al-Nușūṣ al-Juz'iyah. Kairo: Dār al-Shurūq, 2008.

——_. Fiqh al-Wasațiyah al-Islāmiyah wa al-Tajdīd; Ma'ālim wa Manārāt. Markaz al-Qarḍ̄āī, 2009.

-_— Kalimāt fĩ al-Wasațiyah al-Islāmiyah wa Ma'ālimihā. Kairo: Dār alShurūq, 2011.

——_. Kayf Nata'mal ma'a al-Qur'ān al-'Aẓîm. Kairo: Dār al-Shurūq, 2000.

———. Zāhirah al-Ghuluww fĩ al-Takfïr. Kairo: Maktabah Wahbah, 1990.

Al-Qāsimī, Muḥammad Jamāl al-Dīn. Maḥāsin al-Ta'wīl. Dār Ihyā' al-Kutub al-'Arabiyah, 1957.

Al-Qasțalānī, Aḥmad ibn Muḥammad al-Khațīb. Irshād al-Sārī 'ilā Sharḥ Saḥịh al-Bukhārī. al-Maṭba'ah al-Kubrā al-Amīriyah, 1323.

Al-Qaț̣ān, Mannā' Khalīl. Mabāhith fì 'Ulūm al-Qur'ān. Kairo: Maktabah Wahbah, n.d.

Qudāmah, 'Abdullāh ibn Aḥmad ibn Muḥammad ibn. Rawḍah al-Nāẓir wa Jannah al-Manāzir fï Ușūl al-Fiqh. Riyad: Maktabah al-Rush, 1993.

Rabī'ah, 'Abd al-'Azīz ibn 'Abd al-Raḥmān ibn. 'Ilm Maqāṣid al-Shāri'. Riyad: Maktabah al-Mulk, 2002.

Al-Raḥmān, Khālid ibn Ḥusayn ibn 'Abd. Jalīsuk fì Ramaḍān. Riyad: Dār Țawīq, 2002.

Al-Raysūn̄i, Aḥmad. Min A'lām al-Fikr al-Maqāṣidī. Beirut: Dār al-Hādi, 2003.

———. Nazariyah al-Maqāṣīd 'inda al-Imām al-Shāțībī. Riyad: al-Dār al'Alamiyah li al-Kitāb al-Islāmī wa al-Ma'hād al-'Alamī al-Fikr alIslāmī, 1995.

———. Al-Fikr al-Maqāṣidì Qawā'iduh wa Fawā'iduh. Riyad: al-Dār alBayḍa', 1999.

_—_. Al-Madkhal 'ilā Maqāṣid al-Sharī'ah. Kairo: Dār al-Kalimah, 2009.

—_- 'Al-Maqāșid al-Sharīah wa Dawruhā fĩ Istinbāṭ al-Aḥkām'. AlMuslim Al-Mu'āṣir 32, no. 128 (2008).

——_. Al-Tajdīd al-Ușūlī Naḥw Siyāghah Tajdīdiyah li 'Ilm Ușūl al-Fiqh. Beirūt: Dār al-Kalimah, 2015.

_——. Al-Taysīr al-Fiqhī. Beirut: Dār Ibn Hazm, 2007.

———. Maqāṣid al-Maqāṣid. Beirūt: al-Shubkah al-'Arabiyah, 2013. 
———. Muhāẹarāh fi Maqāṣsid al-Sharī’ah. Kairo: Dār al-Kalimah, 2010.

- - N Nazariyah al-Maqāșid 'ind al-Imām al-Shāțibī. Herndon: alMa'had al-'Ālamī li al-Fikr al-Islāmī, 1995.

Al-Rāzī, Muḥammad ibn 'Umar ibn al-Ḥusayn. Al-Maḥșūl fì Ușūl al-Fiqh. Beirut: Mu'assasah al-Risālah, n.d.

Rumadi, ed. Hasil-Hasil Muktamar ke-33 NU. Jakarta: Lembaga Ta'lif wan Nasyr PBNU, 2016.

Al-Sa'd̄̄, 'Abd al-Raḥmān Nāṣir. Al-Qawā'id wa al-Ușūl al-Jāmi'ah. Kairo: Mațba'ah al-Madanī, 1956.

- - Taysīr al-Karīm al-Raḥmān fì Tafsīr Kalām al-Mannān. Riyad: Dār al-Salām, 2002.

Sa'īd, Muhammad Ra'fat. Asbāb Wurūd al-Hadīth Tahlīl wa Ta'sīs. Qatar: Kitāb al-Ummah, n.d.

Al-Sabt, Khālid ibn 'Uthmān. Qawã'id al-Tafsīr Jam'ān wa Dirāsah. Dār ibn 'Affān, 1421.

Saeed, Abdullah. Interpreting the Qur'ān: Toward a Comtemporary Approach. New York: Routledge, 2006.

Al-Sahālawī, Muḥammad ibn Niẓām al-Dīn. Fawātif al-Raḥamūt. Beirut: Dār al-Kutub al-'Ilmiyah, 2002.

Al-Salamī, 'Abd al-Rahīm ibn Șamāyal. Haqīqah al-Lībarāliyah wa Mawqif al-Islām minhā. Jeddah: Markaz al-Ta'ṣil li Dirāsāt wa al-Buhūth, 2009.

Al-Sanīdī, Salmān ibn 'Umar. Tadabbur al-Qur'ān. Riyad: Maktabah alMulk, 2002.

Al-Ṣāwī, Șalāh. Al-Tațarruf al-Dīnī. Al-Āfaq al-Dawliyah li I'lām, n.d.

Al-Shamrī, Thā'ir Ibrāhīm Khudīir. Al-Wasațiyah fì al-'Aqīdah al-Islāmiyah. Beirut: Dār al-Kutub al-'Ilmiyah, 2005.

Al-Shāțibī, Ibrāhīm ibn Mūsā ibn Muhammad. Al-Muwāfaqāt fì Ușūl alSharī'ah. Saudi: Wizārah al-Shu'ūn al-Islāmiyah, n.d.

Al-Shawkānī, Muhammad ibn 'Alī ibn Muhammad. Irshād al-Fuḥul 'ilā Taḥqìq al-Haq min 'Ilm al-Ușūl. Riyad: Dār al-Faḍilah, 2000.

Shubayr, Muhammad 'Uthmān. Al-Qawā'id al-Kulliyah wa al-Dawābit alFiqhiyah fì al-Sharīa ah al-Islāmiyah. Yordania: Dār al-Nafā'is, 2007.

Shuhbah, Muḥammad Abū. Al-Madkhal li Dirāsah al-Qur'ān al-Karīm. Riyad: Dār al-Liwā', 1987. 
Ainol Yaqin

Al-Shuwaykh, 'Ādil. Ta'līl al-Ahkām fì al-Sharī’ah al-Islāmiyah. Ṭanța: Dār al-Bashīr, 2000.

Al-Subkī, 'Abd al-Wahhāb ibn 'Alī ibn 'Abd al-Kāfī. Al-Ibhāj fì Sharh alMinhāj. Kairo: Maktabah al-Kulliyat al-Azhariyah, 1981.

Al-Subkī, 'Alī ibn 'Abd al-Kāfī al-Subkī, and 'Abd al-Wahhāb ibn 'Alī. AlIbhāj fi Sharh al-Minhāj. Kairo: Maktabah al-Kulliyat al-'Azhariyah, 1981.

Al-Sulamī, 'Abd al-'Azīz ibn 'Abd al-Salām. Al-Fawā'id fĩ Ikhtișār alMaqāșid. Beirut: Dār al-Fikr al-Mu'āșir, 1996.

Al-Suyūṭī, 'Abd al-Raḥmān ibn Abū Bakr. Al-Dībāj 'alā Ṣaḥịh Muslim Ibn alHajjāj. Riyad: Dā̀r ibn 'Affān, 1996.

___. Al-Itqān fì 'Ulūm al-Qur'ān. Beirut: Mu'assasah al-Risālah, 2008.

——_. Al-Radd 'alā Man Akhlad 'ilā al-Arḍ wa Jahila anna al-Ijtihād fì Kull 'Așr Farḍ. Kairo: Maktabah al-Thaqāfah al-Dīniyah, n.d.

———. Al-Tawshīḥ Sharh al-Jāmi' al-Ṣaḥịh. Riyad: Maktabah al-Rush, 1998.

———. Lubāb al-Nuqūl fì Asbāb al-Nuzūl. Beirūt: Mu'assasah al-Kutub alThaqāfiyah, n.d.

Al-Tamīmī, Ahmad ibn 'Alī ibn Mathanna. Musnad Abī Ya'lā al-Mawsalī. Beirut: Dār al-Thaqāfah al-'Arabiyah, 1992.

Taymiyah, Aḥmad ibn 'Abd al-Halīm ibn. Muqaddimah fĩ Ușūl al-Tafsīr, 1972.

Al-Ṭayyār, Musā'id ibn Sulaymān ibn Nāșir. Sharh Muqaddimah fĩ Ușūl alTafsīr. Riyāḍ: Dār ibn al-Jawzī, 1428.

Turkī, 'Abd al-Majīd. Munāzarāt fī Ușūl al-Sharī’ah al-Islāmiyah bayn Ibn Hazm wa al-Bājīi. Beirut: Dār al-Gharab al-Islāmī, 1986.

'Ubaydī, Hammādī. Al-Shāțibī wa Maqāṣid al-Sharī'ah. Beirut: Dār Qutaybah, 1992.

Al-'Uthmānī, Sa'd al-Dīn. Al-Dīn wa al-Siyāsah Tamyīz lā Faṣl. Kairo: Dār al-Kalimah, 2015.

Al-Wāhidī, 'Alī ibn Aḥmad. Asbāb Nuzūl al-Qur'ān. Beirut: Dār al-Kutub al'Ilmiyah, 1991.

Al-Wakīlī, Muhammad. Fiqh al-Awwaliyāt Dirāsah fí al-Dawābiț. Herndon: Ma'had al-'Ālamī li al-Fikr al-Islāmī, 1997.

Al-Yahṣabī, Iyāḍ ibn Mūsā ibn 'Iyāḍ. Ikmāl Muslim bi Fawā'id Muslim. Beirut: Dār al-Wafā', 1998. 
Al-Yūbī, Muḥammad Sa'd ibn Aḥmad ibn Mas'ūd. Maqāșid al-Sharī'ah wa 'Alāqatuhā bi al-Adillah al-Shar'iyah. Riyad: Dār al-Hijirah, 1998.

Zahrah, Muhammad Abū. Ibn Hanbal Hayātuh wa 'Așruh Ārā'uh wa Fiqhuh. Kairo: Dār al-Fikr al-'Arabī, n.d.

_-_. Mãlik Hayātuh wa 'Așruh Ārā'uh wa Fiqhuh. Kairo: Dār al-Fikr al'Arabī, n.d.

———. Ușūl al-Fiqh. Beirūt: Dār al-Fikr al-'Arabī, n.d.

Al-Zahrānī, 'Abd al-Karīm ibn Șāliḥ ibn 'Abdullāh. 'Al-Mașābih fī Tafsīr alQur'ān al-'Azīm'. Jāmi'ah Ummu al-Qurā, 2000.

Al-Zarkashī, Muḥammad ibn 'Abdullāh. Al-Baḥr al-Muhit fị Ușūl al-Fiqh. Kairo: Dār al-Ṣafwah, 1992.

———. Al-Burhān fì 'Ulūm al-Qur'ān. Beirut: Dār al-Ma'rifah, 1990.

Al-Zarqā, Muștafā Ahmad. Al-Madkhal al-Fiqhī al-'Ām. Damaskus: Dār alQalam, 2004.

Al-Zarqānī, Muhammad 'Abd al-'Az̄īm. Manāhil al-'Irfān fĩ 'Ulūm al-Qur'ān. Matba'ah 'Īsā al-Bābī al-Halabī wa Sharakāh, n.d.

Al-Zībārī, 'Iyād Kāmil Ibrāhīm. Siyāsah al-Tadarruj fì al-Aḥkām alShar'iyah. Beirut: Dār al-Kutub al-'Ilmiyah, 2017.

Al-Zuhaylī, Wahbah. 'Ușūl al-Fiqh al-Islāmī. Damaskus: Dār al-Fikr, 2009.

———. Al-Wajīz fì Ușūl al-Fiqh. Beirut: Dār al-Fikr, 1999.

———. Qaḍāyā al-Fiqh wa al-Fikr al-Mu'äșir. Damaskus: Dār al-Fikr, 2007. 
